\title{
Destekleme ve Yetiştirme Kursuna Katılan Öğrencilerin Beden Eğitimi ve Spor Tutumları, Sportmenlik Davranışları ve Uygulama Hakkındaki Görüşlerinin İncelenmesi ${ }^{1}$
}

\author{
Investigation of Sportsmanship Behavior and Sports Attitude of Middle \\ School Students According to Their Attendance in Physical Education \\ and Sports Courses and Students Views on This Application
}

\author{
Şahin GÜNBAY², İhsan SARI ${ }^{3}$
}

\section{Öz}

Bu araştırma beden eğitimi ve spor dersi destekleme ve yetiştirme kursuna katılan ve katılmayan ortaokul öğrencilerinin beden eğitimi ve spora karşı tutumları ile sportmenlik davranışlarının incelenmesi ve öğrencilerin bu yeni uygulama hakkındaki görüşlerinin belirlenmesi amacıyla yapılmıştır. Bu çalışmada iki araştırma bulunmaktadır. Birinci araştırmada destekleme ve yetiştirme kursuna katılan 78 öğrenci deney grubu olarak, kursa katılmayan 71 öğrenci ise kontrol grubu olarak belirlenmiştir. Öğrencilere dönem başında ve sonunda Beden Eğitimi ve Spor Tutum Ölçeği ve Beden Eğitimi Dersi Sportmenlik Davranışı Ölçeği uygulatılmıştır. Analizlerde tanımlayıcı istatistikler, bağımsız gruplarda t testi ve eşleştirilmiş gruplarda t testi kullanılmıştır. İkinci araştırmada ise beden eğitimi destekleme ve yetiştirme kursuna katılan 8 öğrenciye odak grup görüşmesi yapılmış ve öğrencilerin destekleme ve yetiştirme kursu hakkındaki görüşleri tespit edilmiştir. Elde edilen sonuçlara göre destekleme ve yetiştirme kursuna katılan deney grubu öğrencilerinin beden eğitimi ve spora karşı tutum ve sportmenlik davranışları son test puanlarında anlamlı düzeyde artış görülmüştür. Nitel veriler incelendiğinde ise beş boyut ortaya çıkmıştır: kazanımlar, kursa yönlendiren, kursa katılma nedeni, yaşanılan sorunlar ve öneriler. Sonuç olarak destekleme ve yetiştirme kurslarının beden eğitimi ve spora karşı tutum ve sportmenlik davranışı için etkili olduğu belirlenmiştir. Ayrıca bu uygulamanın öğrencilere çok yönlü faydaları olduğu belirlenirken, öğrenciler tarafından bazı sorunlar ve öneriler de ortaya koyulmuştur.

Anahtar Kelimeler: Beden eğitimi, destekleme ve yetiştirme kursu, sportmenlik, görüş, tutum

\section{Abstract}

This study was carried out to determine the attitudes of secondary school students who participate in physical education and sports course and those who do not participate in these courses with their attitudes towards physical education and sports and sportsmanship behaviour and to determine students' views about this new practice. There are two separate researches in this study. In the first research, 78 students, who participated in supporting and training courses of physical education were selected as the experimental group. 71 students, as control group, were selected from the students who did not attend these physical education and sport courses. Physical Education and Sport Attitude Scale and Sportspersonship Behaviour Scale in Physical Education Course were applied to students at the beginning and end of the term. Descriptive statistics, independent sample t-test and paired sample t-tests were used in data analysis. In the second study two focus group interviews were conducted with 8 students and their opinions were asked about the support and training courses of physical education and sports. According to the results, there was a significant increase in the post-test scores of the students in attending and training courses towards physical education and sports and sportsmanship behaviours. When the qualitative data in study two is analysed, five dimensions have emerged: achievements, the one led to the course, the reason for participating in the course, problems and suggestions. As a result of these two researches, it was determined that support and training courses of physical education and sports were effective for physical education and sports attitude and sportsmanship behaviour of students. In addition, this new practice of support and training course has been found to have many benefits for the student and some problems and suggestions have been put forward by students.

Keywords: Attitude, physical education, sportsmanship, support and train-ing course, view

${ }^{1}$ Bu araştırma birinci yazarın yüksek lisans tezinden üretilmiştir.

${ }^{2}$ Milli Eğitim Bakanlığı, Güzin Dinçkök Ortaokulu, Maltepe, İstanbul, Türkiye, https://orcid.org/0000-0002-5677-0325

${ }^{3}$ Sakarya Uygulamalı Bilimleri Üniversitesi, Spor Bilimleri Fakültesi, Antrenörlük Eğitimi Bölümü, Sakarya, Türkiye, https://orcid.org/0000-0002-9090-8447 Atıf / Citation: Günbay, Ş., \& Sarı, í. (2020). Destekleme ve yetiştirme kursuna katılan öğrencilerin beden eğitimi ve spor tutumları, sportmenlik davranışları ve uygulama hakkındaki görüşlerinin incelenmesi. Kastamonu Education Journal, 28(2), 910-930. doi:10.24106/kefdergi.697835 


\section{Extended Abstract}

Aim: Supporting and training courses have been opened for the purpose of supporting and educating the students attending official / private formal education institutions that have been put into practice by the Ministry of National Education to close the gap of the closed private teaching institutions since 2014, and limited to the courses in the formal education curriculum. These courses, which include physical education and sports, also offer reinforcement training outside the classroom. In this respect, the frontier for increasing the sporting activities for the physical education and sports class, which is the limited course hour, has been opened. Under normal conditions, a secondary school students who has physical education and sports lesson for one hour a week in imam hatip and vocational schools and 2 hours a week in other schools, has gained the opportunity to see the physical education and sports course for 2 hours extra and 4 hours in total thanks to the new applied and supportive course. Based on the view that there will be various changes in the lives of these students who have increased sportive activity, the idea of what kind of differences may be between the students attending physical education and reinforcement courses has gained importance. In line with the explanations above the aim of this study was to determine the attitudes of secondary school students who participate in physical education and sports course and those who do not participate in these courses with their attitudes towards physical education and sports and sportsmanship behaviour. The second aim of this research was to and to determine students' views about this new practice. There are limited studies about this new practice therefore we believe that the findings of this research will contribute to the relevant literature.

Method: There are two separate researches in this study. The first research was conducted with a quantitative approach. 78 students, who participated in supporting and training courses of physical education, from the middle school students in Maltepe district of Istanbul province were selected as the experimental group of this research. 71 students, as control group, were selected from the students who did not attend these physical education and sport courses. Personal information form, Physical Education and Sport Attitude Scale and Sportspersonship Behaviour Scale in Physical Education Course were applied to students at the beginning and end of the term. All necessary permissions were taken and also ethical approval was obtained from Sakarya University Ethics committee. The data collection took place at the schools in face to face interactions. The obtained data was entered on the computer and later it was checked for incorrect data entering. The data was analysed in SPSS 17 software. Descriptive statistics, independent sample t-test and paired sample t-tests were used in data analysis. The level of significance was determined to be .05 in all the analysis. A qualitative approach was adopted in the second study. Firstly interview questions were formed. A semi-structured interview forms were then sent to two experts in the fields of physical education and qualitative research. For the purpose of the second research, two focus group interviews were conducted with 8 students and their opinions were asked about the support and training courses of physical education and sports. Each focus group was carried out with four students. The data was analysed with content analysis in NVIVO 11 software.

Results: According to the results of the first research, there was a significant increase in the post-test scores of the students in attending and training courses towards physical education and sports $t(77)=-5,78, p<.05$ and sportsmanship behaviours scores (three subscales:avoiding unappropriate behaviours $=t(77)=-4,94, p<.05$, showing appropriate behaviours $=t(77)=-3,57, p<.05$, total sportmenship behavior=t(77)=-4,99, $p>$.05. But there was not any significant difference in control group students in any of the variables. When the qualitative data in study two is analysed, five dimensions have emerged according to the students' statements. These themes were; achievements, the one led to the course, the reason for participating in the course, problems and suggestions.

Conclusion: As a result of these two researches, it was determined that support and training courses of physical education and sports were effective for physical education and sports attitude and sportsmanship behaviour of students. In addition, th is new practice of support and training course has been found to have many benefits for the student and some problems and suggestions have been put forward by students. According to the result of this research some suggestions are presented to improve the functionality of this practice. Also some recommendations were also proposed for the future research. 


\section{Giriş}

1950'li yıllardan sonra öğrencilerin sayısının artması ve yükseköğretime çok miktarda başvuru olması ile birlikte okullardaki derslik, öğretmen ve eğitim araç gereci sayısında yetersizliğe sebep olmuştur. Bu yetersizlik sonucunda, öğrenci ve velilerin okuldaki eğitimi yeterli bulmaması ve öğrencilerin yükseköğretim giriş sınavına daha iyi hazırlanabilmesi amacı ile her geçen yıl dershanelere olan rağbet artmış bu nedenle de çok sayıda dershane açılmıştır (Ören, 2014). Sonuç olarak maddi imkânı iyi olan öğrenciler, dershaneler ve etüt merkezlerinden ücret karşılığı ek hizmet alarak maddi imkânları yeterli olmayan ve aynı imkânlara ulaşamayan diğer öğrencilere karşı yarışmışlardır. Böylece herkes için eşit şartların olmadığı bir yarış ortaya çıkmıştır. Maddi imkânı olmayan öğrenci velileri, çocuklarını dershane, etüt merkezi ve özel derse gönderememiştir. Tüm bunların ise hem anayasanın 10. maddesindeki eşitlik prensibine hem de 1739 sayılı Milli Eğitim Temel Kanunu'na aykırı olduğu ifade edilmiştir. Bu durumu gidermek amacı ile 5580 sayılı Özel Öğretim Kurumları Kanunu'nun ikinci maddesinin birinci fıkrasının (b) bendinde yer alan "dershaneleri” ibaresi 1 Mart 2014 tarihinde yürürlükten kaldırılmıştır (Dönmez, Gürbüz ve Tekçe, 2018). Böylece eğitim veren dershaneler kapatılmıştır. Dershanelerin yerine ise Destekleme ve Yetiştirme Kursları (DYK) açılmıştır (Bozbayındır \& Kara, 2017).

\section{Destekleme ve Yetiştirme Kursları}

Eğitim kurumları, öğrenciler için önceden belirlenmiş olan hedeflerin öğrencilere kazandırılmasını amaçlar. Bu hedeflere ulaşmayı etkileyen birçok unsur vardır ve alan yazında bu unsurlar üzerine birçok araştırma yapıldığı görülmektedir (Aktaş \& Mirzeoğlu, 2009; Özcan, Mirzeoğlu \& Çoknaz, 2016). Fakat çeşitli nedenler ile hedeflenen kazanımların elde edilememesi sonucunda öğrenciler için ekstra öğretim faaliyetleri yapılabilir (Aküzüm \& Saraçoğlu, 2018). DYK'lar bu faaliyetlerden birisidir ve eğitim-öğretim kurumlarında öğrencilere devlet tarafından ücretsiz olarak sağlanmaktadır (Milli Eğitim Bakanlığı, 2014). Beden eğitimi ve spor dersi de DYK'lar kapsamındadır. Yani, öğrenciler DYK'da beden eğitimi ve spor dersini de seçebilmektedir. Beden eğitimi ve spor dersi normalde ortaokullarda haftada iki saat olarak verilmektedir. Ilkokullarda beden eğitimi ve spor dersi "oyun ve fiziksel etkinlik dersi" olarak işlenmektedir (Milli Eğitim Bakanlığı, 2013). DYK'lar, il ve ilçe millî eğitim müdürlüklerinde kurulan komisyonlar tarafından planlanmaktadır (Milli Eğitim Bakanlığı, 2014). DYK'lar il ve ilçe milli eğitim müdürlüklerinin belirlemiş olduğu okul veya eğitim kurumlarının müdürünün teklifi ve ilgili millî eğitim müdürünün onayı ile açılmaktadır. Okullarda açılan kurslar, ders saatleri dışında saat 22.00'ye kadar faaliyet gösterebilmektedir. intiyaç olması halinde cumartesi, pazar günlerinin yanı sıra sömestr ve yaz tatillerinde de DYK'lar açılabilmektedir. DYK kapsamında hangi derslerin açılacağı ise öğrencilerin ve velilerinin talebine göre belirlenmektedir (Milli Eğitim Bakanlığı, 2019; 2018). DYK'lara 2015-2016 eğitim öğretim yılında yaklaşık 9 milyon öğrenci başvurmuş ve 630 bin öğretmen kurslarda görev yapmıştır (Bozbayındır \& Kara, 2017).

DYK'lar son birkaç yıl içinde faaliyete başlamış bir uygulamadır. Bu nedenle bu uygulama kapsamlı olarak ele alınarak olumlu yanlarının ortaya koyulması ve var olan eksikliklerinin belirlenerek tamamlanması gerekmektedir. Ülkemizde bu konuda yapılan araştırmalar incelendiğinde oldukça sınırlı sayıda araştırma yapıldığı görülmektedir. Yapılan güncel araştırmada DYK uygulamasının birçok olumlu yönü ortaya koyulmuştur. Örneğin yapılan bir araştırmada (Dönmez ve diğerleri, 2018) DYK'lar yönetici, öğretmen ve öğrenci görüşlerine göre incelenerek fırsat eşitliği açısından değerlendirilmiştir. Bu araştırmanın sonucuna göre yönetici ve öğretmenler bu DYK'nın fırsat eşitliğini sağladığını ifade ederken öğrenciler ise bu kursların olmaması durumunda bazı öğrencilerin dershane ve özel ders imkanlarından faydalanamayabileceğini ifade etmiştir (Dönmez ve diğerleri, 2018). Benzer şekilde, Nartgün ve Dilekçi (2016) öğretmen ve öğrencilerin DYK hakkındaki görüşlerini görüşme yöntemi ile incelemiştir. Araştırma sonuçlarına göre DYK'nın öğrencilerde derse katılımı arttırması, konu tekrarı sağlaması, ders notlarında artış meydana getirmesi öğrencilerce ifade edilirken; araştırmaya katılan öğretmenler bu uygulamanın özgüven sağladığını, daha fazla soru çözme fırsatı verdiğini ve öğrencilerin derse katılımı artırdığını ifade etmişlerdir (Nartgün ve Dilekçi, 2016). İncirli, ilı̆̆an, Sirem \& Bozkurt'da (2016) "Destekleme ve Yetiştirme Kurslarına illişkin Öğrenci Görüşleri Anketi" adı ile DYK uygulamasını değerlendiren bir ölçme aracı geliştirmek amacı ile bir araştırma gerçekleştirmişlerdir. Araştırma sonuçlarına göre DYK'ye özel bir ölçme aracı ortaya koyan araştırmacılar DYK hakkında öğrenci görüşlerinin olumlu olduğunu ifade etmişlerdir (İncirli ve diğerleri, 2016). Ünsal ve Korkmaz ise (2016) DYK ile ilgili öğretmen görüşlerini incelemiştir. Değişik branşlardaki 20 öğretmen ile görüşerek DYK'nın öğretmenlere ekonomik anlamda katkı sağladığını, bu kursların öğrencilerin ders ve sınav başarılarını arttırıp soru çözme becerilerini geliştirerek öğrencilere katkı sağladığını belirtmişlerdir. Fakat, bu çalışmadaki öğretmenlerin hepsinin branşııın matematik, fen bilimleri, Türkçe gibi teorik dersler olduğu, beden eğitimi öğretmenlerinin Ünsal ve Korkmaz'ın araştırmasına (2016) dahil edilmediği görülmektedir. Bir başka çalışmada ise DYK'nın okul derslerine destek olması, öğretmene maddi destek 
sağlaması, öğretmenlerin mesleki gelişimini sağlaması ve maddi durumu iyi olmayan öğrencilere destek olması gibi katkıları olduğu öğretmenlerce belirtilmiştir (Bozbayındır \& Kara, 2017).

DYK'ların olumlu yönleri kadar olumsuz yönleri de bulunmaktadır. DYK uygulamasının çok yeni bir uygulama olması nedeniyle aksayan yönlerinin olduğunu ve birtakım sorunların yaşanmasının kaçınılmaz görüldüğü ifade edilmiştir. Bu sorunlara yönelik çözüm önerilerinin geliştirilmesi, kursların bireysel ve akademik katkılarıyla sosyal etkilerinin incelenmesi ilgili kursların daha verimli olmasına katkı sağlayacağı ifade edilmiştir. Bu nedenle "Destekleme ve Yetiştirme Kurslarına Yönelik Tutum Ölçeği" geliştirilerek bu uygulamanın araştırmacılar tarafından etkili bir şekilde değerlendirilebilmesi sağlanmıştır. Ayrıca; öğretmenlerin hafta içi ve hafta sonu kurslarda görev almaları nedeniyle fazla yorulabilecekleri ifade edilmiştir. DYK kapsamında sadece sınava yönelik Matematik, Türkçe, Fen Bilimleri vb. dersleri değil, spor, sanat, müzik, drama vb. alanlarda da daha fazla ders açılmasının teşvik edilmesi de önerilmiştir (Aküzüm ve Saraçoğlu, 2018). Bozbayındır ve Kara ise (2017) bazı katkılarının olmasının yanında DYK'larda öğrenci devamsızlığı, kursa yönelik kaynak eksikliği, kursun ücretsiz olmasının ilgiyi azaltması ve öğrencilerin kursu ciddiye almamaları sorunlarını tespit etmişlerdir. Öneri olarak ise DYK'ya yönelik kaynaklar sağlanması, aile ile işbirliği sağlanması, öğrencilere kursun önemi hakkında bilgi verilmesi ve kurslar için aileden ücret talep edilmesi gibi öneriler sıralanmıştır (Bozbayındır ve Kara, 2017). Biber, Tuna, Polat, Altınok ve Küçükoğlu (2017) ise sekizinci sınıf öğrencilerinin DYK ile ilgili görüşlerini incelemiştir. Bu araştırmada DYK'da en çok matematik, Türkçe ve İngilizce derslerinin tercih edildiği, öğrencilerin kursların sınav başarılarında etkili olduğunu düşündü kleri ve bu kursların ücretli olması durumunda öğrencilerin kursa daha çok devam edecekleri belirlenmiştir (Biber ve diğerleri, 2017).

Yukarıdaki ifade edilen bu konudaki güncel araştırmalar incelendiğinde, farklı branşlardaki öğretmenlerin bu uygulama hakkındaki görüşleri ile öğrenci ve yöneticilerin bu uygulamaya yönelik düşüncelerinin araştırıldığı görülmektedir. Fakat yapılan bu araştırmaların çoğunda beden eğitimi branşının incelenmediği ya da beden eğitimi ve spor öğretmenlerinin ifade edilen bu araştırmaların çoğuna dahil edilmediği görülmektedir. Bu nedenle beden eğitimi ve spor dersine özel değerlendirmelerin yapılması ile daha spesifik bulgular ortaya koyulabilir ve bu uygulama için beden eğitimi ve spor dersi özelinde yapılabilecekler belirlenebilir. Yazarların bilgisi dahilinde DYK uygulaması sadece iki farklı araştırma kapsamında bir derse özel olarak incelenmiştir. Bunlardan birincisinde Sarıbaş ve Pınar (2018) ortaöğretim son sınıf öğrencilerinin coğrafya dersinin sınav sistemindeki yerini bilmelerinin DYK kapsamında coğrafya dersini seçmelerindeki etkisini ele almıştır. Bunun dışında yapılan bir pilot çalışmada ise Günbay, Sarı ve Mirzeoğlu (2017) DYK kapsamında olan beden eğitimi ve spor derslerine katılan öğrencilerin görüşlerini incelemiştir. Bu araştırmalarla birlikte coğrafya dersi ve beden eğitimi ve spor dersi özelinde DYK uygulamasının incelendiği görülmektedir. Bu iki araştırmadan başka DYK uygulamasının tek bir ders özelinde derinlemesine değerlendirildiği bir araştırma bulunmamaktadır. Bu açıklamalardan yola çıkarak beden eğitimi ve spor dersi DYK uygulamalarının detaylı olarak ele alınması gerekliliği ortaya çıkmaktadır. DYK'lar ile ilişkili olarak bu araştırma kapsamında incelenecek konulardan birisi beden eğitimi ve spor dersine yönelik tutum diğeri ise sportmenlik davranışıdır. Bu iki konu beden eğitimi ve spor dersi kapsamında öğrenciye kazandırılmaya çalışılan iki önemli unsurdur.

\section{Beden Eğitimi ve Spor Dersine Yönelik Tutum}

Genel olarak "tutum" kavramı, "kişilerin belli bir obje, birey, grup, kuruluş ya da bir fikri onaylama veya kabul etmeme biçimindeki davranışın duygusal bir hazır bulunuşluk şekli ya da yönelimi" şeklinde tanımlanabilir (Özgüven, 2005). Tutum, kişinin etrafındaki belirli bir obje ya da nesneye duyduğu tepki yönelimi olarak varsayılır. Dolayısıyla tutumda konu, herhangi bir nesne, obje, eşya olduğu gibi; herhangi bir kişi, grup veya soyut bir ifade de olabilir. Her kişinin çevresine göre şekillenen, birçok tutum konusu olduğu düşünüldüğünde, bütün konulara farklı bir tutum üretme zorunluluğu oluşmaktadır (İnceoğlu, 2004). Insanlar, doğduklarında herhangi bir tutuma sahip şekilde doğmazlar, tutumları yaşadıkça öğrenirler. Peki, bireyler belirli konular, nesneler veya bireyler hakkındaki tutumlarını ne şekilde belirlerler? Bu sorunun birçok yanıtı olabilir. Bir takım tutumlar kişilerin kendi deneyimlerine dayanırken, bir kısmı ise diğer kaynaklardan edinilir (Kağıtçıbaşı, 2005). Kişilerin tutumlarının oluşmasını etkileyebilecek kaynaklar genel olarak aile, çevrenin etkisi ve doğrudan bireysel deneyimler olarak sıralanmıştır (Aktaran: Oskamp (1977)'den aktaran Sakallı, 2001:111).

Beden eğitimi ve spor dersinde belirlenen amaçlara ulaşılabilmesi için, öğrencilerin beden eğitimi ve spor dersini sevmesi ve beden eğitimi ve spor dersinin öneminin açık bir şekilde kavranması oldukça önem taşımaktadır. Dolayısıyla beden eğitimi ve spor derslerinin istenilen, amaçlara ulaşabilmesi beden eğitimi ve spor dersine ilişkin öğrenci tutumları ile yakından ilgilidir (Başer, 2009). Öğrencilerin başarılarında derse ilişkin tutumları, derslerini olumlu veya olumsuz şekilde etkilemesi nedeniyle diğer derslerde olduğu gibi beden eğitimi derslerinde de öğrenci tutumlarının incelenmesi önemli bir husustur (Güllü \& Güçlü, 2009). 
Öğrencilerin bedensel yetenekleri ve beden eğitimi ve spor dersinde yapılan sportif aktiviteler, beden eğitimi ve spor dersine yönelik tutuma önemli etki yapar. Örneğin, beden eğitimi ve spor dersinde bir jimnastik hareketi ile ilk kez karşılaşan çocuk, hareketi amacına uygun bir şekilde uygulamayabilir. Bununla birlikte, öğrencinin hareketi yapmaya çalışırken sakatlanma ihtimali de bulunmaktadır. Sakatlanan bir öğrencinin, ondan sonraki beden eğitimi ve spor derslerinde jimnastik hareketlerinden korkmasına, jimnastik dersinde yaşamış olduğu sakatlanmaları anımsamasına ve beden eğitimi ve spor dersiyle ilgili olumsuz fikirler oluşturmasına zemin oluşturmaktadır. Bu sakatlanmalara karşı, öğrencinin beden eğitimi ve spor dersine ve jimnastik hareketlerine ilişkin olumsuz tutumlar oluşturması beklenen bir durumdur (Aras, 2013). Beden eğitimi ve spor dersine ilişkin olumsuz tutum geliştiren çocukların, ders verimlerinin ve derse katılım düzeylerinin düştüğü, derse verdikleri önemin azaldığı ve dersin yapılmasında problemlerin meydana geldiği belirtilmektedir (Karadağ, 2010).

\section{Sportmenlik Kavramı}

Sportmenlik kavramı, sporcudan beklenen doğru davranışlar olarak ifade edilebilir. Sportmenliğin tanımı; "Kaybedebilmek ya da şikâyet etmeden mağlup olabilmek, kural dışı davranışlarla kazanmamak ve rakibine iyilik, cömertlik ve nezaketle davranmak" olarak da tanımlanabilir. Sportmenlik; sabır, samimiyet, kendini kontrol, cesaret, küçümsememek, kendine güven, başka bireylerin doğrularına ve fikirlerine saygı duyma, kibarlık, iyilik, onurluluk, ortaklık, asillik ve cömertlik gibi yönleri yansıtmayı gerektirir. Sportmenliğin amaçları arasında oyundaki tansiyonu yükseltmekten ziyade tansiyonu düşürmek hedeflenir (Sakallı, 2001).

Sportmence davranışta rakibe takımdaki işbirliğin gereğine uygun olarak yaklaşım sergilenir. Yarışmanın temel hedefi sporcuların sahip olduğu becerilerin karşılaştırılmasıdır. Sporcuların, kendilerine haksız başarı sağlayan hakem hatalarını kabul edip etmeyeceklerine dair karar vermeleri önemlidir. Çünkü hakem düdüğünden çok bu kararlar spor dalına ilişkin kuralların yanlış uygulanmasını ifade etmektedir (Felicity, 2002). Sportmenlik, sporda ahlâkî davranışı ifade eder ve sporcuların rekabetin olduğu oyunlarda nasıl davranması gerektiğini belirten bir kavramdır. Zaman çalmaya yönelik davranan sporcuları antrenörlerinin uyarması, bir sporcunun rakibini istemeden düşürdükten sonra yerden kaldırmak için ona elini uzatarak iyi olup olmadığını sorması, sporcuların rakibin sağıı̆ını ve güvenliğini düşünerek davranması, sporcuların hakemlerin yanlış çaldıkları düdüklerini düzeltmeleri, kurallara net bir şekilde uyulması sportmen davranışlara örnek olarak gösterilebilir (Tavşancıl, 2002). Beden eğitimi ve spor dersinin amaçlarından birisi de öğrencilerin sportmenlik davranışları kazanmasını sağlamaktır. Okullardaki beden eğitimi ve spor dersinin içeriği çocukların bu özelliğini de geliştirecek yönde hazırlanmıştır. Bu açıklamalar doğrultusunda bu araştırmada aşağıdaki araştırma sorularına cevap aranacaktır.

- Beden eğitimi ve spor dersi destekleme ve yetiştirme kursuna katılımın ortaokul öğrencilerinin beden eğitimi ve spora karşı tutumları ile sportmenlik davranışları üzerinde bir etkisi var mıdır?

- Öğrencilerin beden eğitimi ve spor dersi destekleme ve yetiştirme kursu hakkındaki görüşleri nelerdir?

\section{Yöntem}

\section{Araştırmaların Modeli}

Bu araştırmada nitel ve nicel yöntem kavramlarının birleştirmesi olarak tanımlanan karma yöntem tekniği kullanılmıştır. Araştırmada karma yöntem desenlerinden olan iç içe sıralı desen kullanılmıştır (Creswell \& Clark, 2015). Bu bağlamda bu çalışma kapsamında iki ayrı araştırma gerçekleştirilmiştir. Bu araştırmalar aşağıda detaylı olarak açıklanmıştır.

\section{Birinci Araştırmanın Yöntemi}

Araştırmanın nicel kısmında, biri deney diğeri kontrol olmak üzere iki grup bulunmaktadır. Deney grubu DYK kapsamında beden eğitimi ve spor kursuna katılan öğrencilerden oluşurken, kontrol grubundaki katılımcılar ise DYK kapsamında beden eğitimi ve spor dersine katılmayan öğrencilerden oluşmaktadır. Deney ve kontrol grubuna da DYK uygulamaları başlamadan önce ön test ölçümleri yapılmıştır. Ön test ölçümlerinden sonra deney grubu bir dönem boyunca normal eğitime ek olarak DYK kapsamında beden eğitimi ve spor uygulamalarına katılmıştır. Kontrol grubu ise normal eğitimine devam etmiş, DYK kapsamında beden eğitimi ve spor uygulamasına katılmamıştır. Dört ayın sonunda ise her iki gruba da son test ölçümleri uygulanmıştır. Deneysel araştırmalarda yapılan ön test ve son test sonuçlarına göre kullanılan tekniğin deney grubu üzerinde etkisi araştırılabilir (Büyüköztürk, Çakmak, Akgün, Karadeniz \& Demirel, 2008). Dolayısıyla araştırmada, "ön test-son test eşleştirilmiş kontrol gruplu yarı deneysel desen" kullanılmıştır. Desende hazır olan iki gruptan birisi DYK kursuna katılan grup diğeri ise DYK uygulamasına katılmayan gruptur. İki grupta beden eğitimi ve spora karşı tutum ve sportmenlik davranışı puanları açısından ön test ölçümlerinde birbirine 
denk olmaları sağlanmıştır. íki grubun da ön test puanlarında anlamlı bir farklılığın olmadığı görülmektedir. Yani araştırmanın başında deney ve kontrol gruplarının beden eğitimi ve spora karşı tutum ve sportmenlik davranışı puanları arasında istatistiksel açıdan anlamlı bir fark yoktur.

\section{Çalışma Grubu}

İstanbul ili Maltepe ilçesinde Güzin Dinçkök Ortaokulunda öğrenim görmekte olan 149 öğrenci çalışmaya katılmıştır. Katılımcılar "maksimum çeşitleme" ve "kolay ulaşılabilir durum örneklemesi" yöntemleri beraber kullanılarak belirlenmiştir. Bu öğrencilerden 78'i beden eğitimi ve spor dersi destekleme yetiştirme kursuna katılan deney grubunu oluştururken, diğer 71 öğrenci ise beden eğitimi ve spor dersi destekleme yetiştirme kursuna katılmayan kontrol grubunu oluşturmaktadır. Deney grubunda 31 (39.7\%) erkek 47 (60.3\%) kız, kontrol grubunda ise 33 (\%46.5) erkek 38 (\%53.5) kız öğrenci bulunmaktadır. Tüm öğrenciler 10-14 yaş arasında değişmektedir. Öğrenciler $5,6,7$ ve 8 . sınıflardan karma olarak seçilmiştir. Deney grubundaki tüm öğrenciler ilk kez beden eğitimi ve spor dersi kursuna katılan öğrencilerden seçilmişken kontrol grubundaki öğrenciler daha önce hiç beden eğitimi ve spor kursuna katılmamıştır.

\section{Veri Toplama Araçları}

Beden Eğitimi ve Spor Tutum Ölçeği: Öğrencilerin beden eğitimi ve spor dersine ilişkin tutumlarını tespit etmek amacıyla Demirhan ve Altay (2001) tarafından geliştirilen "Beden Eğitimi ve Spor Tutum Ölçeği” kullanılmıştır (Demirhan \& Altay, 2001). Ölçekte toplam 24 madde bulunmaktadır. Ölçekteki maddelere 1-5 arası (1=kesinlikle katılmıyorum $5=$ =kesinlikle katılıyorum) seçeneklere göre cevap verilmektedir (Örnek madde=Beden eğitimi ve spor etkinliklerinin insanın sağlıklı gelişmesine katkı sağladığına inanırım). Ölçekte tek boyut bulunmaktadır. Bu ölçekten alınabilecek puanlar 24-120 arasında değişmektedir. Alınan yüksek puan beden eğitime ve spor dersine yönelik olumlu tutumu ifade etmektedir. Cronbach Alpha Güvenirlik Katsayısı 0.93 olarak belirlenmiştir (Demirhan \& Altay, 2001).

Beden Eğitimi Dersi Sportmenlik Davranışı Ölçeği: Sportmenlik davranışlarını ölçmek için Koç (2013) tarafından geliştirilen 22 sorudan oluşan Beden Eğitimi Dersi Sportmenlik Davranışı Ölçeği (BEDSDÖ) kullanılmıştır. BEDSDÖ beden eğitimi dersi sportmenlik davranışlarını ölçebilecek güvenilir ve geçerli bir ölçek türüdür. $5^{\prime}$ li Likert tipinde olan ve davranışların sergilenme sıklığını ölçen 22 maddelik ölçeğin 11'er maddeden oluşan iki alt boyutu vardır. ỉki alt boyut puanı toplanarak tek bir toplam puan da hesaplanmaktadır. Alt boyutlardan alınacak minimum puan 11 maksimum puan ise 55'dir. Toplam puanda ise minimum puan 22 maksimum puan 110'dur. Alt boyutlar; "uygun davranışlar sergileme" ve "uygunsuz davranışlardan kaçınma" olarak adlandırılmıştır. Uygun davranışlar sergileme boyutu öğrencilerin beden eğitimi ve spor dersinde sosyal ve resmi kurallar çerçevesinde sergilemesi beklenen ve eğitimcilerin arzu ettiği davranışlarla ilişkilidir (Örnek madde= Beden eğitimi dersinde heyecanlanıp oyun kuralına uymadığımda rakibimden özür dilerim). Uygunsuz davranışlardan kaçınma boyutu ise öğrencilerin beden eğitimi dersinde sosyal ve resmi kurallar açısından kaçınması gerektiği davranışlar ile ilişkilidir (Örnek madde= Beden eğitimi dersinde yendiğim zaman karşı takım oyuncusuyla dalga geçerim). Ölçeğin dereceleme biçimi maddelerde yer alan davranışların sergilenme sıklığını ölçmeye yönelik olarak hazırlanmıştır. Cevap seçenekleri "(1) Hiçbir Zaman" "(5) Her Zaman" şeklinde sıralanmıştır. Ölçeğin tüm maddeleri için hesaplanan Cronbach Alfa güvenirlik katsayısı .88 olarak bulunurken, alt boyutlar için hesaplanan Cronbach Alfa güvenirlik katsayıları .86 ve .84 olarak belirlenmiştir (Koç, 2013).

\section{Verilerin Toplanması}

DYK beden eğitimi ve spor uygulaması haftada 2 saat sürmektedir. Bir eğitim dönemi boyunca DYK beden eğitimi ve spor derslerine katılan deney grubu öğrencileri önceden hazırlanan yıllık kurs planına göre spor dallarına (Futbol, basketbol, voleybol, masa tenisi, badminton) yönelik eğitime tabi tutulmuşlardır. Beden eğitimi öğretmenlerince düzenlenen kurslara devam zorunluluğu bulunmaktadır. İki derse girmeyen öğrenciler kurs sınıflarından çıkarılmıştır. Genel olarak sınıf mevcutlarının 18-20 öğrenci civarında olduğu ve katılımın yüksek olduğu söylenebilir. Kurslar, dersin içeriğine göre okul bahçesinde veya spor salonunda işlenmiştir. Öğrencilerin kursa katılımda son derece istekli olduğu ve spor kıyafetleriyle derse katıldıkları görülmüştür. Bireysel spor dallarında öğrenciler kendilerine ait spor malzemeleriyle derse katıııken takım sporlarında ise beden eğitimi öğretmeni okula ait malzemelerle dersi işlemiştir.

Araştırmada kullanılan veri toplama araçları, 21.09.2017 tarih ve 61923333/044 sayılı Sakarya Üniversitesi Etik Kurulu onayıyla 2017-2018 eğitim öğretim yılında İstanbul ìı Milli Eğitim Müdürlüğünden gerekli izinlerin alınmasından sonra okul idarecilerinin bilgisi ve öğretmenlerin kontrolünde katılımcı öğrenciler uygulanmıştır. Veri toplama araçları (Beden Eğitimi ve Spor Tutum Ölçeği ve Beden Eğitimi Dersi Sportmenlik Davranışı Ölçeği), 2017-2018 eğitim öğretim yılı 1. döneminin başında (ön-test) ve sonunda (son-test) deney ve kontrol gruplarına uygulanmıştır. Böylelikle bir dönem boyunca beden eğitimi kurslarına katılan (deney grubu) ve katılmayan (kontrol grubu) öğrencilerin ön-test ve 
son-test ölçümleri alınmıştır. Ölçekler öğrencilere okuldaki dersliklerinde uygulanmıştır. Araştırmaya katılımın gönüllü olduğu önceden öğrencilere ifade edilmiştir.

\section{Verilerin Analizi}

Elde edilen veriler araştırmacılar tarafından tek tek kontrol edilerek yanlış veya eksik doldurulanlar araştırma dışında tutulmuş, öğrencilere uygulanan anketlerin geçerli ve kabul edilebilir nitelikte olanları, değerlendirilmek üzere kodlanarak bilgisayar ortamına aktarılmıştır. illk olarak hatalı veri girişi olup olmadığı yüzde frekans analizi ile kontrol edilmiştir. Sonrasında ise SPSS 17.0 programında hesaplamalar yapılmıştır. Analizlerde anlamlılık düzeyi .05 olarak bulunmuştur. Verilerin analizinde tanımlayıcı istatistikler, bağımsız gruplarda $t$ testi ve bağımlı gruplarda $t$ testi kullanılmıştır.

\section{Bulgular}

\section{Birinci Araştırmanın Bulguları}

Tablo 1. Beden eğitimi ve spor tutumu ön test puanları ile son test puanlarının grup içi karşılaştırılması

\begin{tabular}{lcccccccc}
\hline \multicolumn{1}{c}{} & \multicolumn{1}{c}{ Ön test } & \multicolumn{2}{c}{ Son test } \\
\hline Grup & Değişken & Ort. & Ss & Ort. & Ss & t & p \\
\hline Deney & Beden eğitimi ve spor tutumu & 93,99 & 15,12 & 107,2 & 11,43 & $-5,78$ & 0 \\
\hline Kontrol & Beden eğitimi ve spor tutumu & 94,42 & 16,22 & 96,08 & 16,19 & $-0,55$ & 0,58 \\
\hline
\end{tabular}

Deney grubunun beden eğitimi ve spor tutumu ön test ve son test puanlarının karşılaştırılması amacıyla gerçekleştirilen bağımlı gruplar t testi analizi sonucuna göre beden eğitimi ve spor tutumu ön test ve son test puanları arasında anlamlı bir farkın olduğu belirlenmiştir $[t(77)=-5,78, p<.05]$. Kontrol grubunun beden eğitimi ve spor tutumu ön test ve son test puanlarının karşılaştırılması amacıyla gerçekleştirilen bağımlı gruplar t testi analizi sonucuna göre, anlamlı bir farkın olmadığı tespit edilmiştir [t(70)=-.55, p>.05].

Tablo 2. Beden eğitimi ve spor tutumu son test puanlarının karşılaştırılması

\begin{tabular}{lcccccc}
\hline Değişkenler & Grup & N & Ort. & Ss & t & p \\
\hline \multirow{2}{*}{ Beden eğitimi ve spor tutumu son test } & Deney & 78 & 107,2 & 11,43 & & \\
& Kontrol & 71 & 96,08 & 16,19 & 4,8 & 0 \\
\hline
\end{tabular}

Deney ve kontrol gruplarının beden eğitimi ve spor tutumu son test puanları arasında anlamlı bir farkın olup olmadığını belirlemeye yönelik yapılan bağımsız gruplarda t-testi analizi sonuçlarına göre anlamlı bir farkın olduğu belirlenmiştir $[\mathrm{t}(147)=4,80, \mathrm{p}<.05]$.

Tablo 3. Sportmenlik davranışı ön test ve son test puanlarının grup içi karşılaştırılması

\begin{tabular}{lllccccc}
\hline \multirow{2}{*}{ Grup } & \multicolumn{2}{c}{ Ön test } & \multicolumn{2}{c}{ Son test } \\
\cline { 2 - 8 } & Değişkenler & Ort. & Ss & Ort. & Ss & t & p \\
\hline \multirow{2}{*}{ Deney } & Uygunsuz davranışlardan kaçınma & 43,7 & 9,19 & 49,7 & 4,89 & $-4,94$ & 0 \\
& Uygun davranışlar sergileme & 38,26 & 8,9 & 43,14 & 8,33 & $-3,57$ & 0 \\
& Sportmenlik davranışı toplam & 81,96 & 15,95 & 92,84 & 11,12 & $-4,99$ & 0 \\
\hline \multirow{2}{*}{ Kontrol } & Uygunsuz davranışlardan kaçınma & 46,1 & 7,12 & 48,2 & 5 & $-1,98$ & 0,05 \\
& Uygun davranışlar sergileme & 36,77 & 9,47 & 39,32 & 8,02 & $-1,65$ & 0,1 \\
& Sportmenlik davranışı toplam & 82,88 & 14,86 & 87,28 & 10,03 & 1,91 & 0,06 \\
\hline
\end{tabular}

Deney grubunun sportmenlik davranışı ön test ve son test puanlarının karşılaştırılması amacıyla yapılan bağımlı gruplar t testi analizi sonucuna göre uygunsuz davranışlardan kaçınma [t(77)=-4,94, p<.05], uygun davranışlar sergileme $[t(77)=-3,57, p<.05]$ ve toplam sportmenlik puanlarında $[t(77)=-4,99, p>.05]$ anlamlı bir farkın olduğu belirlenmiştir ( $p$ <.05). Kontrol grubunun sportmenlik davranışı ön test ve son test puanlarının karşılaştırılması amacıyla yapılan bağımlı gruplar t testi analizi sonucuna göre uygunsuz davranışlardan kaçınma $[t(70)=-1,98, p>.05]$, uygun davranışlar sergileme [t(70)=-1,65, p>.05] ve toplam sportmenlik davranışı puanlarında [t(70)=-1,91, p>.05] anlamlı bir farkın olmadığı tespit edilmiştir. 
Tablo 4. Sportmenlik davranışı son test puanlarının karşılaştırılması

\begin{tabular}{lcccccc}
\hline \multicolumn{1}{c}{ Değişkenler } & Grup & N & Ort. & Ss & t & p \\
\hline \multirow{2}{*}{ Uygunsuz davranışlardan kaçınma } & Deney & 78 & 49,7 & 4,89 & \multirow{2}{*}{0,85} & 0,07 \\
& Kontrol & 71 & 48,2 & 5 & & \\
Uygun davranışlar sergileme & Deney & 78 & 43,14 & 8,33 & 2,85 & 0,01 \\
& Kontrol & 71 & 39,32 & 8,02 & & \\
Sportmenlik davranışı toplam & Deney & 78 & 92,84 & 11,12 & 3,19 & 0,01
\end{tabular}

Deney ve kontrol gruplarının sportmenlik davranışı son test puanları arasında anlamlı bir farkın olup olmadığını belirlemeye yönelik yapılan bağımsız gruplarda t-testi analizi sonuçlarına göre uygun davranışlar sergileme $[\mathrm{t}(147)=2.85, \mathrm{p}<.05]$ ve toplam sportmenlik davranışı puanlarında $[\mathrm{t}(147)=3.19, \mathrm{p}<.05]$ anlamlı bir farkın olduğu belirlenmiştir. Uygunsuz davranışlardan kaçınma puanında ise anlamlı bir farkın olmadığı tespit edilmiştir $[\mathrm{t}(147)=1.85, \mathrm{p}>$.05].

\section{İkinci Araştırmanın Yöntemi}

\section{Araştırma Deseni}

Bu çalışmanın kapsamında yapılan 2. araştırma nitel araştırma yönteminden oluşmaktadır. 2. araştırmada DYK'ya katılan öğrencilerin bu uygulama hakkında görüşleri belirlenmiştir. Bu amaç doğrultusunda 2. araştırmada nitel araştırma desenlerinden olgu bilim tekniği kullanılmıştır. Bireylerin deneyimlerini ve görüşlerini belirtmek için kullanılan olgu bilim deseni, farkında olunan ancak ayrıntılı ve derinlemesine bir bilgiye sahip olunmayan olgulara odaklanmaktadır (Yıldırım \& Şimşek, 2008).

\section{Çalışma Grubu}

Araştırmanın nitel kısmına katılan katılımcılar İstanbul ili Maltepe ilçesinde Güzin Dinçkök Ortaokulunda öğrenim görmekte olan öğrencilerden oluşmaktadır.

\section{Tablo 5. Nitel araştırmaya katılan öğrencilerin bilgileri}

\begin{tabular}{lcccc}
\hline Rumuz & Cinsiyet & Sınıfı & Yaş & Branşı \\
\hline Çınar & Erkek & 5. Sınıf & 11 & Futbol \\
Irmak & Kadın & 5. Sınıf & 11 & Badminton \\
Nehir & Kadın & 6. Sınıf & 12 & Badminton \\
Toprak & Erkek & 6. Sınıf & 12 & Futbol \\
Yamaç & Erkek & 7. Sınıf & 13 & Masa Tenisi \\
Yağmur & Kadın & 7. Sınıf & 13 & Voleybol \\
Bulut & Erkek & 8. Sınıf & 14 & Masa Tenisi \\
Rüzgâr & Erkek & 8. Sınıf & 14 & Futbol \\
\hline
\end{tabular}

Araştırmanın nitel kısmında ise örnekleme yöntemi olarak kolay ulaşılabilir örnekleme, kasti örnekleme ve maksimum çeşitlilik örneklemesi birlikte kullanılmıştır. Bu doğrultuda araştırmacı kolay ulaşabildiği ve en iyi bilgi alabileceğini düşündüğü öğrenciler arasından öğrencilerin bazı özelliklerini gözeterek araştırma grubunu belirlemiştir. Bu doğrultuda hem erkek hem de kız öğrencilerden araştırma grubuna dâhil edilmiştir. Ayrıca her sınıf seviyesinden de öğrencilerin araştırmaya dâhil edilmesine dikkat edilmiştir. Görüşmelere katılan öğrencilerin özellikleri tablo 5'te görülmektedir. Odak grup görüşmesi şeklinde yapılan görüşmeye öğrenciler dörderli gruplar halinde dâhil edilmiştir.

\section{Yarı Yapılandırılmış Görüşme Formu}

Araştırmaya katılan öğrencilerin söz konusu uygulama hakkındaki görüşlerini öğrenebilmek için bir dönem boyunca kursa katılan öğrenciler ile odak grup görüşmesi yapılmıştır. Görüşmelerde yarı yapılandırılmış görüşme formu kullanılmıştır. Sorular ilk olarak araştırmacılar tarafından oluşturulduktan sonra nitel araştırma konusuna ve spor eğitimi konusunda deneyimli iki öğretim üyesinin görüşüne başvurulmuştur. Uzman görüşleri doğrultusunda gerekli düzeltme ve eklemelerin yapılmasının ardından görüşme formu oluşturulmuştur.

Verilerin Toplanması 
1. araştırmadaki etik kurul onayı bu araştırmayı da kapsamaktadır. Nitel araştırma ise odak grup görüşmesi yöntemiyle uygulanmıştır. Görüşme için öğrenci velilerinden çocuklarının çalışmaya katılmalarında herhangi bir sakınca görmediklerine dair yazııı izin alınmıştır. Görüşme yapılan öğrencilere okul idarecileri ve beden eğitimi öğretmenleri vasıtasıyla ulaşılmıştır. Bu araştırmaya başlanmadan önce öğrencilerle bir pilot çalışma yapılmıştır. Bu pilot çalışmada araştırmacı deneyimleyebileceği zorlukları önceden görerek daha optimal şekilde veri toplayabilecek duruma gelmiştir. Pilot çalışma sonrasında ortaya çıkan olumsuz durumlar giderilerek gerekli düzenlemeler yapılmıştır. Görüşmelerde katılımcılara yapılan çalışma ile ilgili önceden detaylı bilgi verilmiştir. Çalışmanın bilimsel amaçla yapıldığı ve öğrenci bilgilerinin gizli tutulacağı öğrencilere belirtilerek katılımcıların gönüllü olması esas alınmıştır. Verilerin toplanmasında katılımcıların onayı ile SONY ICD-PX470 cihazı ile görüşmeler kayıt altına alınmıştır. Gerektiğinde ise kısa notlar da alınmıştır. Verilerin toplanmasının ardından elde edilen ses kayıtları dinlenerek bilgisayar ortamına yazı olarak aktarılmıştır.

\section{Verilerin Analizi}

Görüşme verilerinde ise, görüşmelerin yazılı metne dönüştürülmesinden sonra içerik analizi ile kodlar ve temalar oluşturulmuştur. Verilerin analizi nitel araştırma yöntemleri konusunda deneyimli olan araştırmacı ve yine nitel araştırma yöntemleri konusunda uzman bir kişi tarafından ayrı ayrı yapılmıştır. Analizlerde NVIVO 11 programı kullanılmıştır. Sonrasında ise iki kişi tarafından elde edilen kodlar karşılaştırılmıştır. Bu karşılaştırmada Miles ve Huberman (1994) tarafından önerilen [görüş birliği/(görüş birliği + görüş ayrılığı) X 100] formülü kullanılmıştır. Yapılan hesaplama sonucu \%87i oranında uyuşma bulunmuştur. Uyuşma olmayan tüm kodlar iki araştırmacı tarafından da incelenerek görüş birliğine varana kadar tartışılmıştır. Verilerin raporlanması kısmında tüm katılımcılara birer takma isim verilmiştir. Araştırma içerisinde ifade edilen isimler katılımcıların gerçek isimleri değildir, bu araştırma için kimliklerinin gizli olması açısından onlara verilmiş takma isimleridir. Bulgularda belirtilen kod ve temalar için katılımcıların doğrudan ifadelerine de yer verilmiştir.

\section{Geçerlilik ve Güvenirlik}

Lincoln ve Guba (1986) tarafından pozitivist felsefenin kesinlik varsayımına uygun olarak nitel araştırmalar için güven duyulabilirlik (trustworthiness) terimi önerilmiştir. Nitel araştırmalarda geçerlik güvenirlik için birçok kavram kullanılmaktadır. Bu araştırmalarda niteliği arttırıcı ölçüt ve tekniklerin güven duyulabilirlik kavramı temelinde betimlenmesinin nitel araştırmacıların sıklıkla içine düştükleri kavramsal karmaşayı ortadan kaldırabileceği ifade edilmiştir (Arastaman, Fidan \& Fidan, 2018).

Bu araştırmada da Arastaman vd., (2018) tarafından ifade edilen güven duyulabilirlik; inandırıcılık (credibility), aktarılabilirlik (transferability), güvenilebilirlik (dependability) ve onaylanabilirlik (confirmability) olmak üzere dört ölçüt aracılığı ile sağlanmıştır. İnandırıcılık kavramı bulguların gerçeklikle ne derece uyumlu olduğunu belirtirken, aktarılabilirlik ise bulguların diğer bağlamlara ne düzeyde uyarlanabildiği ile ilgilidir. Güvenilebilirlik, aynı bağlamda aynı katılımcılarla aynı bulgulara ulaşılması şeklinde ortaya koyulmaktadır. Onaylanabilirlik ise bulgularının araştırmacının görüşlerinden kaynaklanmadığını, araştırmaya katılanların deneyim ve düşüncelerinden oluştuğunu ortaya koymaktır (Shenton, 2004). Aşağıda bu araştırmada güven duyulabilirliğin ne şekilde sağlandığı açıklanmaktadır.

İnandırıcılık: Pozitivist paradigmada belirtilen içsel geçerliğin nitel araştırmadaki karşılığının inandırıcılık olduğu ifade edilmektedir (Arastaman ve diğerleri, 2018). İnandırıcılık için yapılanlar:

- Uzun süreli irtibat kurma: Bu araştırmada görüşmeleri gerçekleştiren kişi beden eğitimi ve spor öğretmeni olması nedeniyle araştırmaya konu olan alana hâkimdir. Alanı çok iyi bilmektedir. 5 yıldır beden eğitimi ve spor öğretmeni olarak çalışmaktadır ve kendisi bizzat DYK kurslarında görev almıştır.

- Çeşitleme: Farklı metotların, araştırmacıların, perspektiflerin ve veri kaynaklarının, verilerin ve yorumların çapraz kontrollerini gerçekleştirmek amacıyla bir arada kullanılmasını ifade etmektedir. Bu araştırmada da farklı yaş ve sınıf seviyelerinden öğrencilerden veriler elde edilerek farklı kaynaklardan veri elde edilmesi sağlanmıştır.

- Katılımcı dürüstlüğünü destekleyen taktiklerin kullanımı: Bu husus, yalnızca samimi olarak katkı sağlamak isteyen ve hür iradesiyle veri sunmaya hazır kişilerle veri toplama süreçlerinin yürütülmesini sağlamaktadır. Bu araştırmaya katıım gönüllülük esasına dayanmaktadır. Tüm katıımcılara bu açıklama yapılarak gönüllü olarak katılım sağlamaları ve dürüst cevap vermeleri sağlanmıştır. Katılımcıların isimlerinin araştırmada kullanılmayacağı ve takma isimler kullanılacağı ifade edilmiştir. Araştırmanın herhangi bir aşamasında araştırmadan ayrılabilecekleri de açıkça katılımcılara belirtilmiştir. Ayrıca ses kaydının ve görüşme metinlerinin sadece araştırmacılar tarafından görüleceği başka kimsenin bu verilere ulaşamayacağı da açıklanmıştır. Sorulacak sorularda doğru cevaplar olmadığı ve bu araştırmanın amacının katılımcıların deneyimlerini belirlemek olduğu da 
katılımcılara açık bir şekilde ifade edilmiştir. Böylelikle katılımcıların dürüst bir şekilde cevap vermeleri sağlanmıştır.

- Araştırmacının özgeçmişi, nitelikleri ve deneyimleri: Nitel araştırmada ana veri toplama ve analiz aracı araştırmacıdır. Bu nedenle araştırmacının güvenilirliği, inandırıcılığı sağlamada önemli bir etkendir. Araştırmacı beden eğitimi ve spor öğretmenliği mezunudur. Beş yıldır beden eğitimi ve spor öğretmeni olarak görev yapmaktadır. Ayrıca bu araştırmanın konusu olan DYK kurslarında bizzat görev almıştır. Ayrıca bu araştırmaya veri toplanmadan önce nitel araştırma ve NVIVO yazılımı kullanımına yönelik Ankara'da düzenlenen bir haftalık bir eğitime katılarak başarı ile bu eğitimi tamamlamıştır. Sonrasında NVIVO programını lisanslı olarak alarak uygulamalar yapmıştır. Bu araştırmanın pilot çalışması için öğrenciler ile DYK konusunda bir ön çalışma gerçekleştirilmiştir. Günbay ve diğerleri (2017) tarafından hazırlanan araştırma ekibinde yer almıştır. Söz konusu çalışma 16. Spor Bilimleri Kongresi'nde bildiri olarak sunulmuştur. Bu araştırmada DYK konusunda veri toplama, analiz etme ve raporlama süreçleri gerçekleştirilerek süreçte yaşanabilecek zorluklar ve çözüm yolları belirlenmiştir.

- Kodlayıcılar arası güvenilirlik: Araştırmada elde edilen kodlar iki uzman tarafından karşılaştırılmıştır. Bu karşılaştırmada Miles ve Huberman (1994) tarafından önerilen [görüş birliği/(görüş birliği + görüş ayrılığı) X 100] formülü kullanılmıştır. Yapılan hesaplama sonucu \%87 oranında uyuşma bulunmuştur. Uyuşma olmayan tüm kodlar iki araştırmacı tarafından da incelenerek görüş birliğine varana kadar tartışılmıştır.

- Önceki araştırma sonuçlarıyla karşılaştırma: Bu husus araştırma sonuçlarının geçmişte yapılan çalışma sonuçlarıyla ne derece uyumlu olduğunun değerlendirilmesidir. Bu araştırmadan elde edilen bulgular yapılmış çalışmalar ışığında değerlendirilmiştir.

Aktarılabilirlik: Pozitivizme göre araştırmanın dışsal geçerliği bulguların genellenebilirliği ile ilişkilidir. Fakat nitel araştırmalar geçekleştiren sosyal-kuramcı yaklaşım genellenebilirlikten kaçınır. Çünkü toplumsal/davranışsal fenomenler bağlam ile ilişkilidir (Guba, 1981). Bu nedenle genellenebilirlik yerine aktarılabilirlik ölçütü önerilmektedir (Lincoln \& Guba, 1986). Aktarılabilirlik; daha önce tamamlanmış bir araştırmanın bazı bulgularının, bu bulguların anlamları ve yorumlanmasının benzer durumlara ne derecede uyarlanabildiğiyle ilgili bir kavramdır. Bulguların aktarılabilirliği için araştırmaya etki eden bağlamsal faktörlerin ve örneklem seçim yönteminin eksiksiz bir şekilde betimlenmesi gerekmektedir (Arastaman ve ark., 2018). Bu nedenle bu araştırmaya katılan tüm kişilerin detaylı bilgisi demografik bilgiler olarak tablolarda belirtilmiştir. Araştırma grubunun belirlenmesinde "kasti", "maksimum çeşitleme" ve "kolay ulaşılabilir durum örneklemesi" kullanılmıştır. Örnekleme yöntemi de dikkat edilen hususlar da ayrıntılı olarak yukarıda çalışma grubu başlı̆̆ı altında betimlenmiştir. Ayrıca verilerin toplanması başlığı altında da görüşmelerin detaylı bir tasviri yapılmıştır.

Güvenilebilirlik: Guba (1981) pozitivizmin güvenirlik ölçütünü kullandığını belirtmiştir. Nitel araştırmada ise güvenilebilirlik kavramının kullanılması gerektiğini önermektedir. Güvenilebilirlik; araştırmanın bulguları ve yorumlarının tutarlı bir sürecin ürünü olmasını belirtir. Yani bulguların elde edildiği sürecin açık ve tekrarlanabilir olmasını ifade etmektedir. Güvenilebilirlik için bu araştırmada izlenen tüm basamaklar çok ayrıntılı olarak belirtilmiştir. Nitel araştırma, beden eğitimi ve spor psikolojisi alanında uzman araştırmacılar, soruların hazırlanmasından başlayan, verilerin elde edilip değerlendirilmesi ve yorumlanması sürecinin tümünü yakından takip etmişler ve birçok aşamaya dâhil olmuşlardır.

Onaylanabilirlik: Onaylanabilirlik bulguların araştırmacının inançları, arzuları ve önyargılarından oluşmadığını, araştırılan fenomeni içerdiği ile ilgili bir kavramdır. Onaylanabilirlikte bulgularının araştırmacının özellikleri ve seçimlerinden değil katılımcıların kendi kişisel deneyim ve düşüncelerinden kaynaklandığı ortaya koyulmalıdır (Arastaman ve diğerleri, 2018). Bu noktada iki araştırmacının birden verileri analiz etmesi ve karşılaştırma yapması onaylanabilirliğe bir kanıt olarak sunulmuştur. Ayrıca katılımcılardan elde edilen ifadeler hiç değiştirilmeden bulgular kısmında verilmiştir. Farklı yaş ve sınıf seviyelerindeki öğrencilerden veri toplayarak farklı görüşlerden ifadelere yer vererek bunları yorumlamak da bu araştırmanın onaylanabilirliğine bir kanıt olarak sunulabilir.

\section{İkinci Araştırmanın Bulguları}

Araştırmaya katılan öğrencilerin DYK hakkındaki görüşleri beş ana tema altında sınıflandırılmıştır. Elde edilen bu ana temalar; DYK'ya katılma nedeni, DYK'ya yönlendiren, kazanımlar, yaşanılan sorunlar ve öneriler olarak belirlenmiştir (şekil 1). Yani, 2. araştırmada elde edilen tüm verilerin özeti şekil 1'de ana temalar olarak görülmektedir. Sonrasında ise şekil 2,3,4,5 ve 6'da her ana temaya ait alt temalar ve bu temalardaki kodlar açıklanacaktır. 


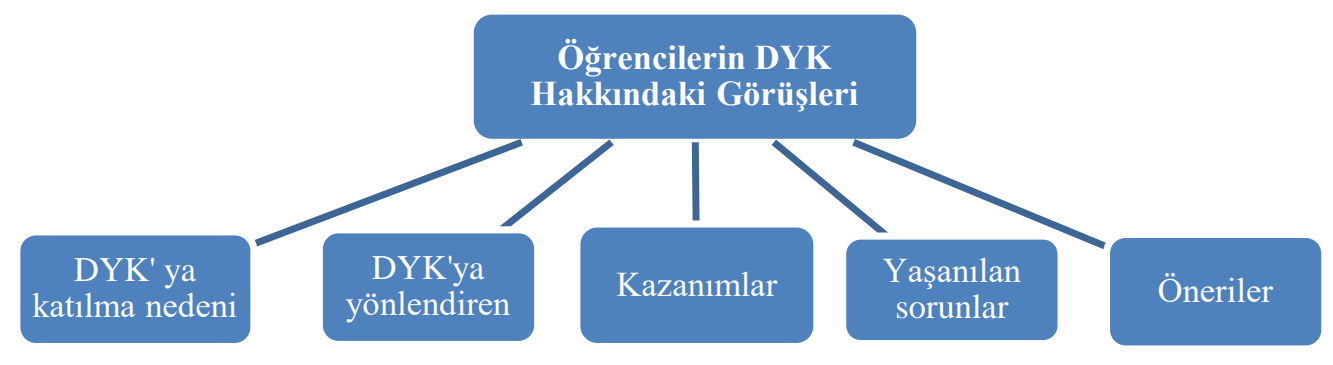

Şekil 1. Öğrencilerin DYK hakkındaki görüşlerine yönelik elde edilen tüm temalar

\section{DYK' ya katılma nedeni temasına ilişkin bulgular}

Öğrencilerin DYK'ya katılma nedenleri incelendiğinde beş neden ile öğrencilerin DYK kapsamında beden eğitimi ve spor dersini tercih ettikleri belirlenmiştir.

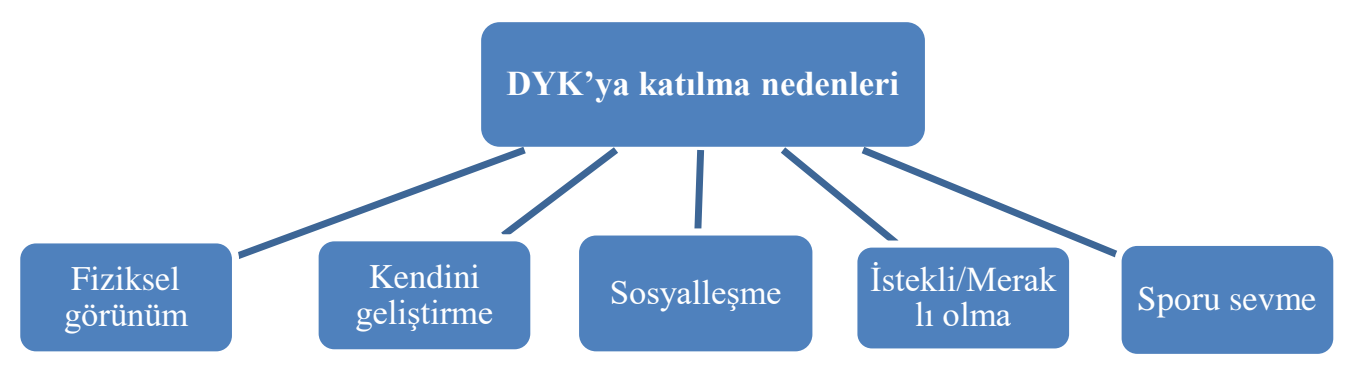

Şekil 2. Öğrencilerin dile getirdiği DYK'ya katılma nedeni teması ve alt temaları

Öğrencilerin DYK'ya katılma nedenleri fiziksel görünüm, kendini geliştirme, sosyalleşme, istekli/meraklı olma ve sporu sevme olarak belirlenmiştir (şekil 2).

Örneğin araştırmaya katılan öğrencilerden Yağmur, fiziksel olarak kendini geliştirmek amacıyla kursa katıldığını belirterek; "Sporun fiziksel olarak gelişmek için iyi bir şey olduğunu herkes biliyor. Ben de bunun için beden eğitimi kursuna katılmaya karar verdim" diye ekleme yapmıştır. Ayrıca bazı öğrenciler DYK'ya sportif anlamda kendilerini geliştirmek amacıyla katıldıklarını belirttiler. Bu öğrencilerden Rüzgar şu görüşlere yer verdi: "Kursa kendimi geliştirmek amaçı olarak katılmıştım zaten. Ben hani okulumuzda olan sınıflar arası turnuvalarda, futbol turnuvalarında, müsabakalarda yer alırken hocalarımız tabi beni şey olarak, bir yetenek olarak istediler. Ben de geldim."

\section{DYK'ya yönlendiren temasına ilişkin bulgular}

Bu kategori altında öğrencilerin DYK'da beden eğitimi ve spor dersini seçmelerinde kimlerin yönlendirici rol oynadığı ifade edilmiştir. Bu kategoride öğrencileri kursa yönlendirenlerin; aile, arkadaş, beden eğitimi öğretmeni ve öğrencinin kendi kararı olduğu belirlenmiştir (şekil 3). 


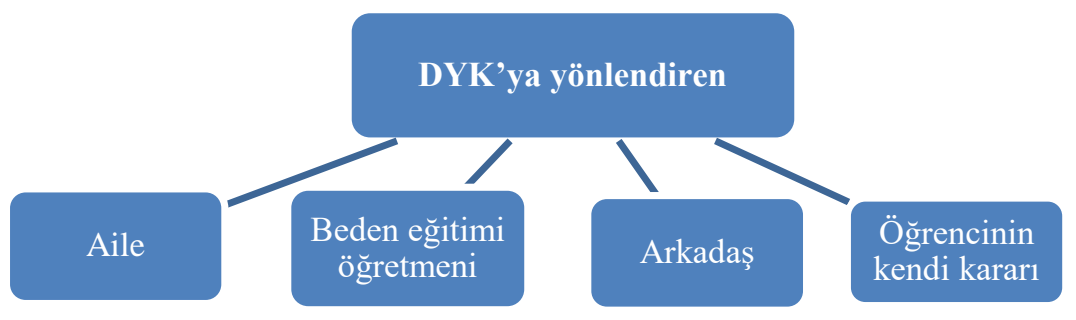

Şekil 3. Öğrencileri DYK'ya yönlendirenler teması ve alt temaları

Örneğin araştırmaya katılan öğrencilerden kurslara katılmalarında ailelerinin etkili olduğunu ifade eden öğrencilerden Nehir, ailesinin verdiği desteğin altını çizerek şöyle ekledi: "Ailem destek verdi. Genel olarak okulda yaptığım herhangi bir spor yoktu. Boş geçiyordu. O yüzden beden eğitimi kursuna katılmak istedim. Ailem de destek verdi." Yamaç ise DYK'ya kendisini yönlendiren birlikte spor yaptığı bir arkadaşı olduğunu ifade etmiştir.

\section{Kazanımlar temasına ilişkin bulgular}

Öğrencilerin DYK kapsamındaki kazanımları incelendiğinde psikolojik, fiziksel-fizyolojik, sosyal ve bireysel kazanımlar elde ettikleri görülmektedir (şekil 4).

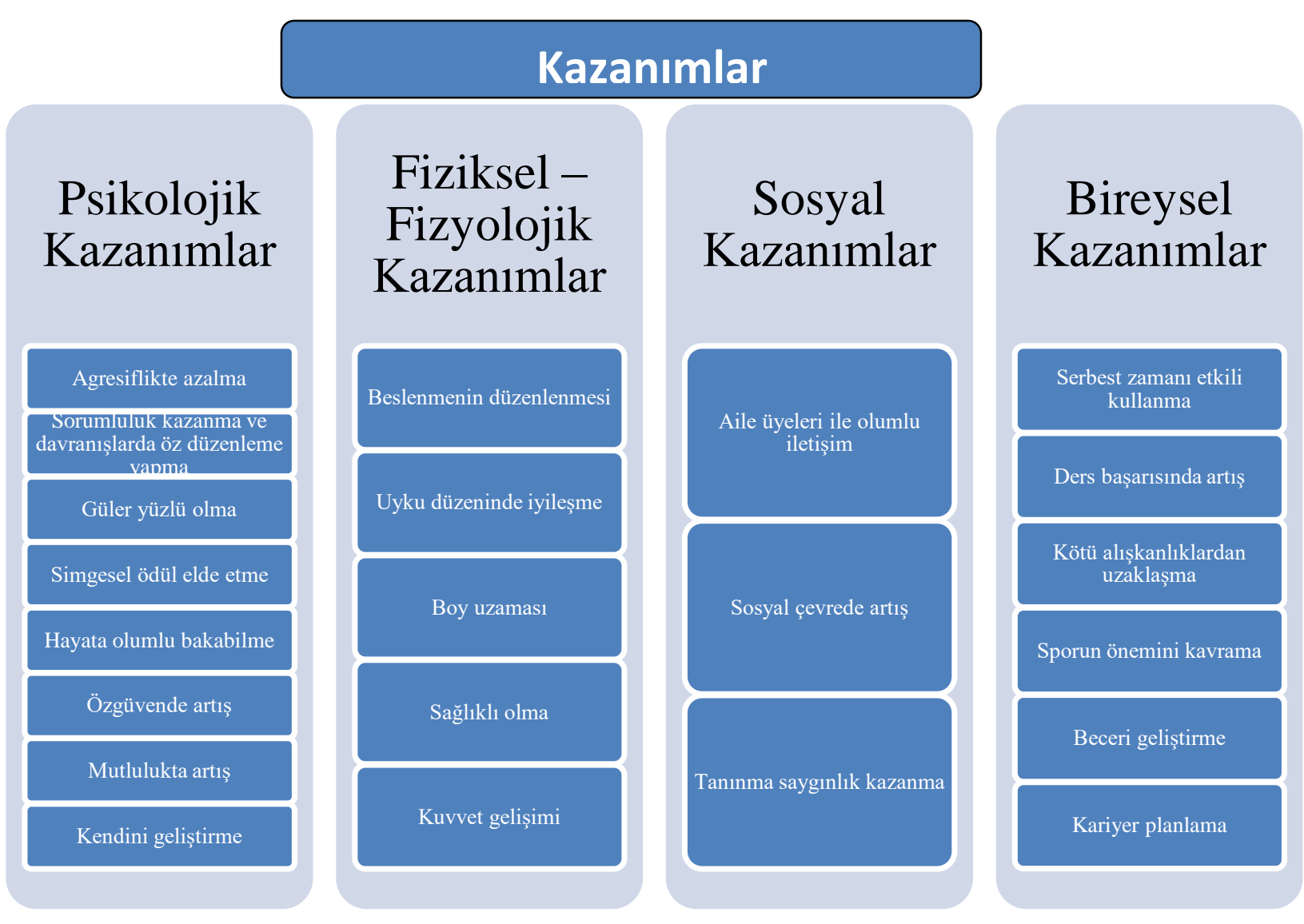

Şekil 4. Öğrencilerin dile getirdiği kazanımlar teması ve alt temaları

Psikolojik kazanımlar: Bu alt temada öğrencilerde agresiflikte azalma, sorumluluk kazanma ve davranışlarda öz düzenleme yapma, güler yüzlü olma, simgesel ödül elde etme, hayata olumlu bakabilme, özgüvende artış, mutlulukta artış ve kendini geliştirme gibi konular ifade edilmiştir. Örneğin, görüşlerini ifade eden Yağmur şunları ifade etmiştir: "Okul takımına katılmadan önce uyku düzenim çok bozuk olduğu için sürekli agresif davranıyordum. Yani hiç kimseyle doğru düzgün konuşamıyordum. Sürekli içime kapanık oluyordum. Ama şimdi sosyal çevrem daha çok arttıkça insanlara davranışımda böyle daha güler yüzlü oldum." DYK sonucunda daha güler yüzlü olduğunu belirten Yağmur şunları ekliyor: "Şimdi sosyal çevrem daha çok arttıkça insanlara davranışımda böyle daha güler yüzlü oldum." 
Fiziksel - Fizyolojik kazanımlar: Bu alt temada öğrenciler beslenmenin düzenlenmesi, uyku düzeninde iyileşme, boy uzaması, sağlıklı olma ve kuvvet gelişimi gibi konuları vurgulamışlardır. Örneğin, DYK ile beslenme alışkanlığında çeşitli değişimler yaşayan Yağmur şöyle konuştu: "Hocam ben zaten çok zayıf bir kızım. Bu yüzden voleybola başladığımdan beri daha çok dikkat ediyorum. Sürekli meyve falan tüketmeye çalışıorum." Katıldığı DYK kursu sonucunda uyku düzeninde gelişme kaydettiğini belirten Irmak ise: "Eskiden dediğim gibi yoktu uyku düzenim. Ve ailemle bunun üzerinde biraz sıkıntı yaşamıştık. Ancak spor dediğim gibi sorumluluk alınca insan tabi mecburen erken uyuyup dinç kalkmak gerekiyor. O yüzden daha erken kalkıp daha erken yatıyorum."

Sosyal kazanımlar: Bu alt tema içerisinde öğrencilerin sosyal yönden ifade ettikleri kazanımlar bulunmaktadır. Bu kazanımlar; aile üyeleri ile olumlu iletişim, sosyal çevrede artış ve tanınma saygınlık kazanma olarak üç tanedir. Örneğin, kurslar sonucunda yeni arkadaşlıklar edindiğini söyleyen öğrencilerden Yamaç: "Şimdi ise spor yapıyorum ve çevrem daha iyi geliştiği için spor hem bana huzur veriyor hem de rahatlatıyor insanı. Kurs sonucu bir sürü arkadaşım oldu. Hiç tanımadığım arkadaşlarımı bile tanıdım, arkadaşım oldu” dedi.

Bireysel kazanımlar: Yukarıdaki kategoriler dışındaki bireysel kazanımlar ise bu alt tema altında sınıflandırılmıştır. Bu kazanımlar; serbest zamanı etkili kullanma, ders başarısında artış, kötü alışkanlıklardan uzaklaşma, sporun önemini kavrama, beceri geliştirme ve kariyer planlama olarak isimlendirilmiştir. Örneğin; DYK ile spor yapmaya başladıktan sonra kötü alışkanlıklardan uzaklaştığını ifade eden Yamaç şunları eklemiştir: "Sosyal olarak hocam, ben kurslara gittiğimden beri mesela artık arkadaşlıklarım daha iyi. Mesela dışarıda arkadaş edindiğinde genelde serseri çıkıyor. Sigara içiyor, ben onlarla arkadaşlık kursam beni de öyle yapabilirlerdi ama ben masa tenisi sayesinde daha iyi arkadaşlar edindiğime inanıyorum." Öğrenciler sportif gelişimleri sonucunda ilerleyen zamanlarda önemli şeyler başaracağını belirttiler. Kariyer planlamayı ifade eden öğrencilerden Bulut, şu ifadelere yer verdi: "...ilerleyen zamanlarda güzel şeyler olabileceğini düşünüyorum. Hocam ilerleyen zamanlarda profesyonel bir futbolcu olmayı düşünüyorum"

\section{Yaşanılan sorunlar temasına ilişkin bulgular}

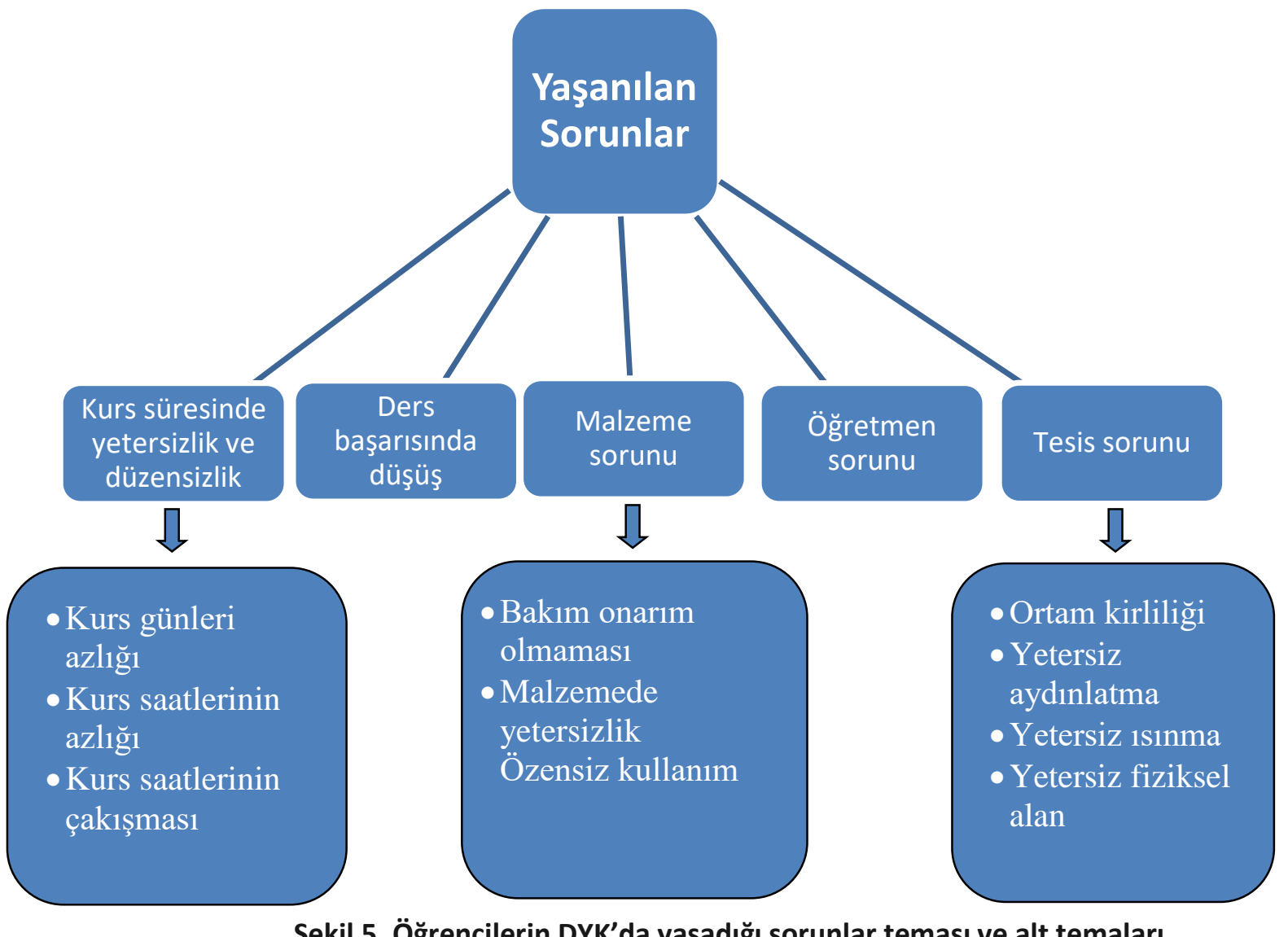

Şekil 5. Öğrencilerin DYK'da yaşadığı sorunlar teması ve alt temaları

DYK beden eğitimi ve spor kapsamında bazı sorunlar olduğunu ifade eden öğrenciler şunları belirtmiştir; Kurs süresinde yetersizlik ve düzensizlik, ders başarısında düşüş, malzeme sorunu, öğretmen sorunu ve tesis sorunu (Şekil 5).

Kurs süresinde yetersizlik ve düzensizlik 
Kurs süresinde yetersizlik olduğunu belirten öğrenciler; kurs günleri azlığı, kurs saatlerinin azlığı ve kurs saatlerinin çakışmasını vurgulamışladır. Örneğin; DYK'lardaki derslerin bazen başka kurs ve derslerle çakıştığını ifade eden öğrenciler bu durumun soruna yol açtığını belirtiler. Görüşmeye katılan öğrencilerden Rüzgar: "Dersin içeriği hakkında bence biraz saati daha da iyi belirlenmeli. Çünkü ders saatine gelebiliyor bazı kurslarımız. Bu yüzden mesela o derse gitmedik mi eve geldiğimizde o dersten mesela ödev veriliyor biz bilmiyoruz ve yapmıyoruz..." diye belirtmiştir.

\section{Ders başarısında düşüş:}

DYK'lar ile birlikte bazı öğrenciler ders başarısında düşüş yaşadığını belirtmiştir. Bu öğrencilerden Çınar: "Benim derslerimi biraz olumsuz yönde etkiledi. Çok fazla olmasa da hocam beni 1-2 puan geriye götürdü. Ama hocam ben bir dahaki senelerde derslerimi düzeltmeyi düşünüyorum" diye belirtti.

\section{Malzeme sorunu:}

Öğrenciler bakım onarım olmaması, malzemede yetersizlik ve malzemelerin özensiz kullanımı gibi konuların altını çizmiştir. Örneğin; Araştırmaya katılan öğrencilerin büyük çoğunluğu kurslarda kullandıkları malzemelerin kalitesizliğine ve yetersizliğine dikkat çektiler. "Mesela hocam ben 5. sınıftan beri gittiğim için 5. sınıfta raketlerimizin yarısı soyuk tahta falan, turnuvaya gittiğimizde turnuvaya raket bile götüremedik, başkalarının raketiyle oynardık" (Çınar). Yine görüşmeye katılan öğrencilerden Toprak ve Nehir malzemelerin ciddi anlamda tahrip olduğunu, daha kaliteli malzemelerle antrenman yapmak istediklerini eklediler.

\section{Öğretmen sorunu}

Görüşmeye katılan öğrencilerden Bulut, öğretmenlerin daha ilgili olması istediğini belirtmiştir.

\section{Tesis sorunu}

Tesisler ile ilgili olarak; Ortam kirliliği, yetersiz aydınlatma, yetersiz ısınma ve yetersiz fiziksel alan sorunları belirtilmiştir. Örneğin; Spor tesislerinin kirliliğinden şikâyetçi olan Yağmur, "Beden eğitimi derslerinde ve kurslarda ögrenciler spor tesislerini kirletiyor. Biz bundan çok şikayetçiyiz" demiştir. Irmak ise: "Tesislerimizin daha çok büyütülüp soyunma kabinlerinin olmasını istiyorum." diye eklemiştir. Toprak ise: "Biz sporcular sonuçta bu tesisleri kullanıyoruz. Duş alamıyoruz. Spordan çıkıyoruz eve o terle gidiyoruz. Olmuyor." demiştir.

\section{Öğrencilerin DYK ile ilgili önerilerine ilişkin bulgular}

Öğrencilerin DYK ile ilgili olarak kurs saati ve öğretmenle ilgili öneriler sundukları görülmektedir (şekil 6).

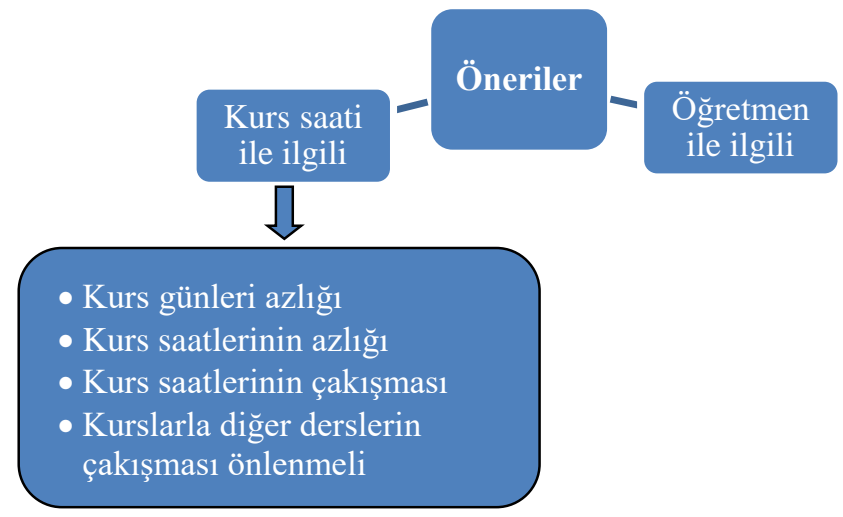

Şekil 6. Öğrencilerin dile getirdiği DYK ile ilgili önerileri teması ve alt temaları

Kurs saati ile ilgili:

Öğrencilerin kurs saatleri ile ilgili önerileri dört alt tema altında değerlendirilmiştir. Bunlar; kursların çakışmasının önlenmesi, kurs saatinin arttırılması, kurs saatlerinin değiştirilmesi ve kurslarla diğer derslerin çakışmasının önlenmesidir. Örneğin; öğrenciler kurs saatlerinin çakıştığını bu çakışmanın da ders tercihi yapmada sorunlara yol açtığını dile getirmişlerdir. Bu konuya dikkat çeken Yamaç şu ifadelere yer verdi: "Hocam bence ders ve kurs saatleri çok birbirine çakışıyor..." Öğrencilerin büyük çoğunluğu ise kurs saatlerinin yetersizliğine dikkat çekmiştir. Örneğin, Bulut ders saatlerinin artması gerektiğini belirterek: "Hocam beden eğitimi destekleme kursunda antrenmanların az olduğunu düşünüyorum..." demiştir.

Öğretmen ile ilgili: 
Kursa katılan öğretmenlerin daha çok kendileriyle ilgilenmesini isteyen öğrenciler buna paralel olarak kurs saatlerinin artmasını istiyorlar. Örnek olarak bu konuda görüşlerine yer veren Bulut: "Hocam beden eğitimi destekleme kursunda antrenmanların az olduğunu düşünüyorum. Hocaların daha çok ilgilenmesini istiyorum" şeklinde konuşmuştur.

\section{Tartışma}

\section{Birinci Araştırmaya Yönelik Tartışma}

Son test ölçümleri sonucu beden eğitimi DYK kursuna katılan deney grubu öğrencilerinin beden eğitimi ve spor etkinliklerine daha çok katıldığı için beden eğitimi ve spora yönelik tutumlarında ve sportmenlik davranışlarında anlamlı düzeyde artı̧̧ olduğu ifade edilebilir. Kursa katılmayan kontrol grubu öğrencilerinin ise beden eğitimi ve spora yönelik tutum ile sportmenlik davranışı puanlarında herhangi bir anlamlı değişiklik bulunmamıştır.

Alan yazın incelendiğinde DYK uygulaması ile ilgili araştırmaların olmasına karşın yapılan bu araştırmalarda sadece beden eğitimi derslerinin incelenmediği bütüncül bir yaklaşım ile DYK'nın genel olarak değerlendirildiği görülmektedir. Ayrıca yapılan araştırmalar sadece DYK hakkındaki öğrenci, öğretmen ya da yönetici görüşlerine yöneliktir (bkz. Göksu \& Gülcü, 2016; Dönmez ve diğerleri, 2018; Nartgün \& Dilekçi, 2016; Ünsal \& Korkmaz, 2016; Bozbayındır \& Kara, 2017; Aküzüm \& Saraçoğlu, 2018; Biber ve diğerleri, 2017). Bu araştırmada ise DYK deneysel bir desen içinde değerlendirilmiştir. Sonuç DYK beden eğitimi ve spor kursunun beden eğitimi ve spor tutumu ile sportmenlik davranışlarına olumlu etkisi olduğu belirlenmiştir. DYK kapsamında her hafta düzenli olarak beden eğitimi ve spor dersine katılan öğrencilerin, beden eğitimi dersi ile hareketli yaşama ihtiyaçlarını karşılaması, enerjilerini boşaltmaları ve okulun sporla eğlenceli hale gelmesi sonucu beden eğitimi dersine ilişkin tutumlarının olumlu olarak değiştiği ifade edilebilir.

DYK kapsamında bu şekilde bir deneysel araştırma olmadığı için benzer araştırmalar ile bulgular tartışılacaktır. Örneğin, Tanrıverdi (2016)'nin ortaokul öğrencilerinin beden eğitimi ve spora karşı tutumunu belirlemek üzere yapmış olduğu çalışmada ortaokul öğrencileri spor faaliyetlerine katılırken yeni beceriler elde etmekte, oyun kurallarını öğrenmekte, kuralları öğrenen öğrencilerin yeni beceriler edinmesiyle beraber spor faaliyetlerinden haz ve heyecan duymakta, spor yoluyla yeni ortam ve arkadaşlar edinmektedirler. Dolayısıyla sporu bu denli seven öğrencilerin beden eğitimi ve spor dersine ilişkin tutumlarının spor yapmayan öğrencilerin tutumlarına kıyasla daha olumlu olabilmektedir.

Sportmenlik davranışına ilişkin bulgular değerlendirildiğinde de DYK kapsamında beden eğitimi ve spor kursuna katılan öğrencilerin beden eğitimi ve spor aktivitesinde daha çok yer alma imkânı bulduğu ve sportmenlik davranışlarının artıı̆ı belirlenmiştir. Takım arkadaşığı, sporun öğretici faktörü ve eğitimle bütünleşmiş sportif aktivite yoluyla DYK'ya katılan öğrencilerin sportmenlik davranışında olumlu yönde artış olduğu söylenebilir. Grupla hareket etme ve takım olmanın beraberinde getirmiş olduğu kurallar, bireyde sportmenlik davranışını geliştirici pozitif katkı yapması beden eğitimi ve sporun temel sonuçlarından biridir. Beden eğitimi ve sporun bireylerin etik değerler ve sportmenlik anlayışı üzerinde önemli ölçüde etkisi olduğu bilinen bir gerçekliktir. Sporun etik değerleriyle ilgili sporcularda bilinçlendirme ve yapısal gerekli değişiklikleri sağlama çalışmalarına ilişkin, özellikle beden eğitimi ve spor dersleri ile okullar arası müsabakaların, sporculara sportmenliğe uygun tutum kazandırması ve sergilenmesinde doğru bir alan olarak kullanılması gereklidir (Türkmen \& Varol, 2015)

\section{İkinci Araştırmaya Yönelik Tartışma}

İkinci araştırmada DYK beden eğimi kursuna katılan öğrencilerin bu uygulama hakkındaki görüşleri değerlendirilmiştir. Bu araştırma kapsamında elde edilen bulgular, ortaya çıkan temalar özelinde aşağıda tartışılmıştır.

Öğrenciler DYK beden eğitimi ve spor dersinin birçok faydasının olduğunu belirtmiştir. Psikolojik kazanımlar teması incelendiğinde araştırmaya katılan öğrencilerin genel olarak DYK kapsamında beden eğitimi ve spor derslerinde psikolojik olarak önemli kazanımlar elde ettiği görülmüştür. Daha çok spor yapmaya başlayan öğrenciler zamanla agresiflikte azalma, sorumluluk kazanma, güler yüzlü olma, davranışlarda öz düzenleme yapma, hayata olumlu bakabilme, daha azimli olma, özgüven ile mutlulukta artı̧̧ ve kendini geliştirme gibi pozitif kazanımlar elde etmiştir. Günümüz şartlarında birçok psikolojik hastalıklarla uğraşan bireylerin deşarj olmaları için spor vazgeçilmez bir uğraş olarak görülebilir. Eğitim çağının her kademesinde beden eğitimi ve spor etkinlikleri düzenlemek ve öğrencileri bu etkinliklere yönlendirmek eğitimin temel hedefleri arasında yer almalıdır. Çocuklara yapılacak en büyük yatırımlardan biri onlara spor yapma alışkanlığı kazandırmaktır.

Çocuk yaştaki bireylerin hayatının merkezinde oyun oynama ve eğlenme isteği vardır. Günümüzde bu ihtiyacını sanal oyunlarla gidermeye başlayan çocuklar için spor yapmak büyük önem kazanmaya başlamıştır. Yılmaz'ın (2012) 
öğrencilerle yaptığı görüşmeden elde ettiği verilerin araştırma bulguları ile örtı̈ştüğü görülmüştür. Yılmaz'ın (2012) araştırmasında öğrencilerin, beden eğitimi ve spor dersini eğlenmek, güzel vakit geçirmek, yorgunluk ve stres atmak, zihinsel olarak dinlenmek için diğer derslere göre daha serbest bir ders olarak görmektedir. Yapılan araştırmalar, beden eğitimi ve spor etkinliklerine katılımın zaman içerisinde bireyi agresif davranışlardan uzaklaştırdığı ve duygu kontrolü sağladığını göstermektedir. Taşkın’ın (2018) 601 öğrencinin katııımıyla yapmış olduğu araştırmada öğrencilerin büyük bir kısmı beden eğitimi derslerinin psikolojik bir etken olan duygu kontrolünü geliştirdiği sonucunu ifade etmiştir. Bu yönüyle sportif etkinliklere katılan öğrencilerin daha mutlu bireyler olduğunu, akranlarına kıyasla daha iyi bir gelişim süreci kaydettiklerini söylemek mümkündür. Altıntaş'ın (2006) konuya dair yaptığı benzer araştırmada beden eğitimi ve spor dersleri hakkında görüş belirten birçok öğrenci beden eğitimi ve spor dersinin stres, kaygı gibi olumsuzlukları aşmak için bir araç olarak görmektedir. Günbay ve diğerleri (2017) araştırmasında da DYK beden eğitimi ve spor dersinin öğrencilerde birçok kazanım sağladığı belirtilmiştir.

Öğrencilerin ifade ettikleri kazanımlarda oluşan bir boyut ise "fiziksel ve fizyolojik kazanımlardır." Bu temada farklı görüşler belirten öğrenciler beslenme düzeni, uyku düzeninde iyileşme, boylarının uzaması, sağlıklı olma ve kuvvet gelişimi gibi konularda geliştiklerini ifade etmişlerdir. Her hafta daha fazla fiziksel etkinlik yapma imkanı olan deney grubu öğrencilerinin bir dönem katıldıkları beden eğitimi ve spor DYK etkinlikleri sonunda çeşitli fiziksel ve fizyolojik kazanımlar elde etmiştir. Taşkın (2018)'ın araştırmasında ortaokul öğrencilerinin büyük bir kısmı beden eğitimi ve spor derslerinin sağlıklarını korumada ve vücut kondisyonunu arttırmada yardımcı olduğu belirtmişlerdir. Yılmaz (2012)'ın araştırmasına katılan beden eğitimi öğretmenleri ise beden eğitimi ve spor derslerine etkin katılım sağlayan öğrencilerin fiziksel gelişimine dersin pozitif katkı sağladığı görüşünü savunmuşlardır. Bu sonuçlar araştırma bulguları ile örtüşmektedir. Bireylerin normal bir gelişim kaydetmesinin temel unsurlarından biri de düzenli fiziksel aktivite yapmasıdır.

Ortaya çıkan bir diğer tema ise sosyal kazanımlardır. Düzenli bir şekilde beden eğitimi ve spor etkinliklerine katılan öğrencilerin zaman içerisinde aile ilişkilerinde gelişim gösterdikleri, yeni edindikleri arkadaşlıklarla sosyal çevrelerinde artış olduğu bunun sonucunda ise tanınmışlık ve saygınlık kazandıkları sonucuna ulaşılmıştır. Sosyal açıdan gelişen öğrencilerin bu durumu diğer davranışlarını olumlu yönde etkilediği görülmüştür. Kurs sonucunda özgüveni gelişen öğrencilerin okul içerisinde sorumluluk aldıkları, kendini daha iyi ifade eder hale geldiği bulgular sonucunda anlaşılmıştır. Spor yapmadan önce kendini ifade etme ve arkadaşlık ilişkilerinde sorun yaşayan öğrencilerin sportif becerilerini sergileyerek ihtiyaç duydukları özgüvene ulaştıkları görülmüştür. Sporla beraber takım olma ve işbirliği becerisi gelişen bireylerin sosyal hayatta daha uyumlu bireyler haline geleceği ifade edilebilir. Güray (2002),'ın yaptığı benzer bir araştırmada ise, bedensel etkinliklerin ergen bireylerin toplumsal gelişimi açısından önemli olduğu ifade edilmiştir. Takım sporlarına katııı öğrenci-öğretici işbirliğini geliştirmekte, saldırgan davranışları doğal yolla ve sosyal kurallara bağlı olarak ortadan kaldırmayı öğretmektedir (Güray, 2002). Grup halinde yapılan faaliyetler insan ilişkileri nedeniyle bireylerin sosyalleşmesine katkı sağlamaktadır. Beden eğitimi ve spor dersi de bu faaliyetler çerçevesinde değerlendirilebilir. Takım veya grup şeklinde spor yapmak birden fazla kişiyle etkileşim halinde olma anlamına gelmektedir. Son olarak, ifade edilen diğer kazanımlar bireysel kazanımlar olarak tanımlanmıştır. Örneğin, araştırmaya katılan bazı öğrenciler daha çok spor yapmanın teorik derslerdeki başarılarına katkı yaptığını ifade etmişlerdir. Spor yaparak fiziksel ve zihinsel zindelik elde eden öğrencilerin zamanla ders başarısında artış olduğu sonucuna varılabilir. Bunun yanı sıra DYK'lara katılan öğrencilerin serbest zamanlarını daha verimli kullandıkları, kötü alışkanlıklardan uzak durdukları, sporun önemini kavrayarak bu alanda kendilerine bir kariyer planı yapabildiklerini belirtmişlerdir. Tokat (2013)'ın araştırması için beden eğitimi ve spor öğretmenleri ve okul yöneticileri ile yapmış olduğu görüşmede katılımcılar, beden eğitimi ve spor dersinin öğrencilerin teorik derslerdeki başarısını olumlu yönde etkilediğini ve dersin öğrencilerin günlük yaşamda karşılaştıkları sorunları belirli ölçüde giderdiği görüşünü ifade etmişlerdir. Aynı şekilde araştırmaya katılanlar beden eğitimi ve spor derslerinin üniversiteye hazırlanan öğrencilerin başarısını olumlu yönde etkilediğini, öğrencilere ders çalışma konusunda işbirliği yapma alışkanlığı ve birlikte hareket etme alışkanlığı kazandığını belirtmişlerdir. Şahin (2011)'in çalışmasında olduğu gibi okul müdürleri beden eğitimi ve spor derslerini bir rahatlama aracı olarak görmektedirler. Araştırmaya katılan okul müdürlerinin çoğunluğu beden eğitimi ve spor derslerinin öğrencilerin girmiş olduğu sınavları pozitif yönde etkilediğini belirtmiştir.

Öğrencilerin bu uygulamaya yönelik olarak ifadeleri değerlendirildiğinde DYK beden eğitimi ve spor dersi kapsamında birçok olumsuzluk olduğu da görülmektedir. Öğrenciler daha çok spor yaptıkları için genel olarak DYK'dan memnun gözükse de uygulamanın henüz yeni oluşu ve okulların fiziki şartları nedeniyle birçok sorunun da olduğu belirlenmiştir. Bu sorunlar; kurs süresinde yetersizlik ve düzensizlik, tesis ve malzeme sorunu, ders başarısında düşüş, öğretmenler ile ilgili sorunlardır. 
Çalışmada odak grup görüşmelerine katılan öğrenciler kurs günlerinin azlığı, kurs saatlerinin azlığı ve kurs saatlerinin çakışması gibi sorunlara dikkat çekmişlerdir. Daha çok spor yaparak kendilerini mutlu hissettiklerine vurgu yapan öğrenciler, DYK kapsamında açılan beden eğitimi ve spor kurs saatinin yetersiz olmasını bir sorun olarak görmektedirler. Hafta boyunca teorik derslerin yoğunluğuyla bir hayli sıkılmaya başlayan öğrencilerin beden eğitimi ve spor dersleri sayesinde zihinsel bir rahatlama yaşadığı görülmektedir. Bu nedenle, haftada iki saat olan beden eğitimi ve spor kurs saatinin arttırılarak haftanın çeşitli günlerine dağılmasını isteyen öğrenciler beden eğitimi ve spor derslerinin daha fazla olmasını istemektedirler. Alan yazında DYK ile ilgili henüz yeterli çalışma olmadığından beden eğitimi ve spor dersleriyle ilgili yapılan araştırmaların bu çalışma ile benzerlik gösteren kısımları tartışmanın bu kısmına yön verebilir. Örneğin, Yılmaz (2012)'ın yapmış olduğu araştırma incelendiğinde çalışmaya katılan bazı öğrencilerin beden eğitimi ve spor ders saatini yetersiz gördükleri belirtilmiştir. Beden eğitimi ve spor ders saatinin yetersiz olduğunu ifade eden öğrenciler zihinsel olarak dinlenmek, deşarj olmak ve diğer derslerin stresinden ve yoğunluğundan uzaklaşmak için beden eğitimi ve spor derslerinin son saatlere alınması ve haftanın en az iki gününe yayılması gerektiğini düşünmektedirler.

Araştırmaya katılan öğrenciler DYK'da kullanılan spor malzemeleri ile ilgili bakım onarım olmaması, malzeme yetersizliği ve özensiz malzeme kullanımı gibi sorunlara vurgu yapmışlardır. Malzeme konusunda sorun yaşayan öğrencilerin kurs verimliliğinin düştüğünü ifade etmişlerdir. Spor tesisi ve spor malzemesi konularının beden eğitimi ve spor dersinin verimli bir şekilde işlenmesi için önemli etkenler olduğu alan yazındaki ilgili araştırmalarda da ifade edilmiştir (Salman, Sarı \& Mirzeoğlu, 2018; Özcan, Mirzeoğlu \& Çoknaz, 2016; Tokat, 2013; Şahin, 2011; Gülüm \& Bilir, 2010; Demirhan, Coşkun \& Altay, 2002; illkim, 2006; Salman, Çalgın \& Salman, 2005; Karakuş, 2005; Sönmez, 1989; Yılmaz, 2012; Taşmektepligil, Yılmaz, İmamoğlu, \& Kılcıgil, 2006; Özşaker \& Orhun, 2005; Ocak \& Tortop, 2006).

Malzemelerin öğrenciler tarafından özensiz kullanımı ile ilgili öğrenci görüşleri değerlendirildiğinde bu konunun çevresine duyarlı ve okullarda öğrencilerin kullanımına sunulan malzemeleri koruyan bireyler yetiştirmek için önemli olduğu görülmektedir. Malzemelerin özenli bir şekilde kullanımı konusunda öğrencilerin bilinçlenmesi hem çevresine zarar vermeyen bireylerin yetiştirilmesini sağlarken, okullardaki malzemelerin ve diğer fiziki yapıların daha uzun süreli ve verimli şekilde kullanılmasını sağlayacaktır. Bu konuda öğrenciler, beden eğitimi ve spor öğretmenleri, okul idarecileri ve ailelere eğitimler verilebilir. Ayrıca bu konuya özel projeler ile bireylerin bu konuda hassas davranmaları sağlanabilir. Araştırmada ortaya çıkan bir diğer başlık ise yetersiz fiziksel alandır. Öğrenciler giyinme odası, duş ve antrenman alanlarının eksikliğini ifade ederek bu eksikliklerin onların beden eğitimi ve spor deneyimlerini olumsuz etkilediğini belirtmişlerdir. Ayrıca beden eğitimi ve spor derslerinin daha etkili ve verimli işlenmesi için spor tesisinin olması büyük önem taşımaktadır. Orta kuşakta yer alan ülkemiz dört mevsimin yaşandığı bir ülke konumuna sahiptir. Bu durum iklim şartlarından ötürü beden eğitimi ve spor dersinin dış ortamda işlenmesini zorlaştırmaktadır. Her dersin nasıl uygulama alanı varsa, beden eğitimi ve spor dersinin verimli şekilde ve düzenli olarak uygulanmasında spor salonu olması öncelikli olarak görülmektedir. Spor salonu olmayan okullarda beden eğitimi ve spor dersleri etkili bir şekilde işlenememektedir. Bu nedenle okullarda spor tesisinin olması beden eğitimi dersinin etkili bir şekilde işlenmesini sağlayacaktır. Tokat (2013)'ın çalışması için görüşme gerçekleştirdiği öğretmen ve okul yöneticilerinin görüşlerinin bu araştırma bulguları ile örtüştüğü görülmektedir. Görüşmeye katılan öğretmen ve idareciler çoğu okullardaki malzeme eksikliği ve spor tesisi olmayışı nedeniyle beden eğitimi ve spor dersinin verimli bir şekilde işlenemediğini ifade etmektedirler. Yılmaz (2012)'ın çalışması da bu araştırma bulguları ile paralellik göstermektedir. Söz konusu araştırmaya katılan bazı okul yöneticileri beden eğitimi ve spor dersi için ihtiyaç duyulan spor tesisi ve yeterli spor malzemesi olmadığından, beden eğitimi ve spor öğretmenlerinin ders programındaki hedefleri gerçekleştirmekte güçlük yaşadıklarını ifade etmişlerdir.

Okul ders saatleri dışında DYK kapsamında açılan beden eğitimi ve spor kursuna katılan bazı öğrenciler spora daha çok zaman ayırdıklarından ders başarııında düşüş yaşadıklarını belirtmişlerdir. Literatürde spora zaman ayıran öğrencilerin diğer derslerini ihmal ettiği ve bunun sonucunda ders başarısının düştüğü tezini savunan ifadeler bulunmaktadır (Yılmaz, 2012; Öncü, 2007). Özellikle okul idarecileri ve velilerin beden eğitimi ve spor dersine ilişkin görüşlerine bakıldığında bu tarz söylemlerin olduğu görülmüştür. Bu çalışmalardan biri olan Yılmaz (2012)'ın araştırmasında beden eğitimi ve spor dersine ilişkin görüş belirten okul yöneticileri, sınavlardan dolayı beden eğitimi ve spr dersinin diğer derslerin başarılarını düşüreceğine inanan bazı öğrencilerin olduğu ve bundan ötürü beden eğitimi dersinden kendilerini soyutlayan öğrencilerin bulunduğunu belirtmişlerdir. Oysaki spor yapmanın bireyin bilişsel fonksiyonlara ve akademik başarıya pozitif katkı yaptığı bilimsel bir gerçekliktir (Singh, Saliasi, Van Den Berg, Uijtdewilligen, De Groot, Jolles, ... \& Ericsson, 2019; Pellicer-Chenoll, Garcia-Massó, Morales, Serra-Añó, SolanaTramunt, González \& Toca-Herrera, 2015). Bu nedenle anne-babaların ve öğrencilerin bu olumsuz önyargıya karşı doğru şekilde bilinçlendirilmesi gerekmektedir. 


\section{Sonuç}

Araştırmaya konu olan okullarda henüz yeni uygulanmaya başlanan destekleme ve yetiştirme kursu uygulaması hakkında bu makale kapsamında iki ayrı araştırma yürütülmüştür. Birinci araştırmada beden eğitimi ve spor kursuna katılan öğrenciler ile katılmayan öğrencileri bir eğitim dönemi sonunda karşılaştırılarak beden eğitimi ve spora karşı tutumları ile sportmenlik davranışları tespit edilmiştir. i̇kinci araştırmada ise kursa katılan öğrencilerin kurs sonunda DYK beden eğitimi ve spor dersi hakkındaki görüşleri değerlendirilmiştir. Birinci araştırmada deney ve kontrol grubu ön test ve son test sonuçlarına göre DYK beden eğitimi ve spor dersine katılan deney grubu öğrencilerinin beden eğitimi ve spor tutumu ile sportmenlik davranışlarında anlamlı düzeyde artış olduğu görülmüştür. DYK kapsamında beden eğitimi ve spor dersine katılmayan kontrol grubu öğrencilerinde ise her iki değişken içinde son test puanlarında anlamlı bir değişim olmamıştır.

- İkinci araştırmada öğrencilerin DYK beden eğitimi ve spor dersindeki deneyimleri ile ilgili yapılan odak grup görüşmeleri sonucunda öğrencilerin kursa katılımları sonucunda;

- Psikolojik, fizyolojik, sosyal ve çeşitli bireysel kazanımlar elde ettikleri belirlenmiştir.

- Beden eğitimi kursu seçmelerinde aile, öğretmen ve arkadaş çevrelerinin etkili olduğunu belirten öğrencilerin DYK'ya katılma nedenleri ile elde ettikleri kazanımlar arasında paralellik olduğu saptanmıştır.

- Kursa katılan öğrenciler henüz yeni uygulanmaya başlayan DYK ile ilgili deneyimledikleri sorunları dile getirmişlerdir. Tesis, malzeme, ders başarısında düşüş ve kurs saatinde yetersizlik gibi sorunlara dikkat çekilmiştir.

- Öğrenciler görüşmelerde kurslarla ilgili çeşitli önerilerde bulunmuşlardır.

\section{6. Öneriler}

Araştırma bulguları doğrultusunda beden eğitimi destekleme ve yetiştirme kurslarının kalitesinin artırılması için şu önerilerde bulunulabilir:

- Beden eğitimi ve spor kursları için ihtiyaç duyulan araç-gereç, malzeme ve tesis ihtiyacı giderilmelidir. Tesislerdeki soyunma odası, duş alma, Isıtma ve temizlik gibi sorunlar giderilmelidir.

- DYK kapsamındaki kursların başka kurslar ve derslerle çakışmasının önüne geçilmelidir. Bu yönde okul idareleri yapmış oldukları ders programlarında gerekli tedbirleri almalıdır. Ayrıca bu konu için çeşitli yazılımlar kullanılabilir veya tasarlanabilir.

- Öğrencilerin daha çok spor yapması için beden eğitimi ve spor kurs gün ve saatleri arttırılmalıdır. Kendini ifade etmede sorun yaşayan, sosyal ilişkilerden uzak ve benzeri problemler yaşayan öğrenciler sosyal hayata adapte olmaları için beden eğitimi DYK kurslarına katılmaya teşvik edilmelidir.

- Beden eğitimi ve spor öğretmenleri görevini yerine getirirken daha özverili olmalı. Öğrencilerle yakından ilgilenmelidir. Ayrıca çağın gereklerine uygun olarak sürekli kendini geliştirmeli ve güncellenmelidir.

\section{İleride Yapılabilecek Araştırmalara Yönelik Öneriler}

- Araştırma için DYK konusunda farklı eğitim kurumlarından daha fazla öğrenciyle görüşme yapılabilir.

- Okul idarecileri, öğretmenler ve velilerin de destekleme ve yetiştirme kurslarına yönelik görüşleri alınabilir.

- Araştırma kapsamı genişletilebilir. İl ve ilçeler arasında karşılaştırmalar yapılarak yeni uygulamanın olumlu ve olumsuz yönleri ortaya konulabilir.

- Çalışma süresi arttırılarak, benzer çalışmalar planlanabilir. Böylelikle uygulama hakkında daha geniş detaylı bulgulara ulaşılabilir.

\section{Kaynakça}

Aktaş, L. P., \& Mirzeoğlu, D. E. (2009). Ilköğretim II. kademe öğrencilerinin öğrenme stillerinin okul başarılarına ve beden eğitimi dersine yönelik tutumlarına etkisi. Spormetre Beden Eğitimi ve Spor Bilimleri Dergisi, 7(1), 1-8.

Aküzüm, C., \& Saraçoğlu, M. (2018). Ortaokul öğretmenlerinin destekleme ve yetiştirme kurslarına yönelik tutumlarının incelenmesi. Turkish Journal of Educational Studies, 5(2), 97-121. 
Altıntaş, H. A. (2006). Mardin Midyat'taki ilköğretim kurumlarında islenen beden eğitimi derslerine yönelik öğrencilerin, öğretmenlerin ve yöneticilerin görüşleri, Ankara Üniversitesi, Sağlık Bilimleri Enstitüsü, Ankara

Aras, Ö. (2013). Illköğretim kurumları ikinci kademede Öğrenim gören öğrenci ve görev yapan beden Eğitimi öğretmenlerinin beden eğitimi dersine Yönelik görüş ve tutumlarının incelenmesi (Kars ili örneği), Gazi Üniversitesi Eğitim Bilimleri Enstitüsü Beden Eğitimi Ve Spor Öğretmenliği Ana Bilim Dalı, Ankara

Arastaman G., Fidan i.Ö., \& Fidan T., (2018). Nitel araştırmada geçerlik ve güvenirlik: Kuramsal bir inceleme. Yüzüncü Yıl Üniversitesi Eğitim Fakültesi Dergisi, 15(1), 37-75.

Başer, S. A. (2009). Öğretmen Niteliklerinin Beden Eğitimi Dersi Alan Öğrencilerin Bu Derse Karşı Olan Tutumlarına Etkisi. Abant İzzet Baysal Üniversitesi, Sosyal Bilimler Enstitüsü, Bolu.

Biber, AÇ., Tuna, A., Polat, AC., Altınok, F., \& Küçükoğlu, U. (2017). Ortaokullarda uygulanan destekleme ve yetiştirme kurslarına dair öğrenci görüşleri. Bayburt Eğitim Fakültesi Dergisi, 12(23), 103-119.

Bozbayındır, F., \& Kara, M. (2017). Destekleme ve Yetiştirme Kurslarında (DYK) Karşılaşılan Sorunlar ve Öğretmen Görüşleri Temelinde Çözüm Önerileri. Sakarya University Journal of Education, 7(2), 336-349.

Büyüköztürk, Ş., Çakmak, E. K., Akgün, Ö. E., Karadeniz, Ş. Demirel, F. (2008). Bilimsel Araştırma Yöntemleri. Ankara: Pegem Akademi.

Creswell W, P. Clark V. (2015) Karma Yöntem Araştırmaları, Çeviren: Dede Y. Demir S. B, 2. Baskı, Anı Yayıncılık, Ankara

Demirhan, G, Altay F. (2001). Lise 1. sınıf öğrencilerinin beden eğitimi ve spor dersine ilişkin spor ölçeği, Spor Bilimleri Dergisi, 12(2) s:9-20

Demirhan, G., Coşkun, H., Altay, F.. (2002). Beden Eğitimi Öğretmenlerinin Niteliklerine İlişkin Görüşler, Eğitim ve Bilim Dergisi, 27(123), 35-41

Dönmez, İ., Gürbüz, S., \& Tekçe, M. (2018). Destekleme ve Yetiştirme Kurslarının Fırsat Eşitliği Açısından Yönetici, Öğretmen ve Öğrenci Görüşlerine Göre Değerlendirilmesi. Eskişehir Osmangazi Üniversitesi Türk Dünyası Uygulama ve Araştırma Merkezi Eğitim Dergisi, 3(2), 45-58.

Felicity, H. (2002). Eğitimde Etik, Çev. Semra Kunt-Akbaş, Ayrıntı Yayınları, İstanbul, ss.20-22.

Göksu, İ. ve Gülcü, A., (2016). Ortaokul ve Liselerde Uygulanan Destekleme Kurslarıyla İlgili Öğretmen Görüşleri. Bayburt Eğitim Fakültesi Dergisi, 11(1), 153-171.

Guba, E. G. (1981). Criteria for assessing the trustworthiness of naturalistic inquiries. Educational Technology research and development, 29(2), 75-91.

Güllü M., Güçlü M. (2009). Ortaöğretim Öğrencileri İçin Beden Eğitimi Dersi Tutum Ölçeği Geliştirilmesi. Niğde Üniversitesi Beden Eğitimi ve Spor Bilimleri Dergisi, 3(2), 138-151.

Gülüm, V., \& Bilir, P. (2011). Beden eğitimi öğretim programının uygulanabilme koşulları ile ilgili beden eğitimi öğretmenlerinin görüşleri. Spormetre Beden Eğitimi ve Spor Bilimleri Dergisi, 9(2), 57-64.

Günbay, Ş., Sarı, İ., Mirzeoğlu, D. (2017). Ortaokul öğrencilerinin beden eğitimi dersi destekleme ve yetiştirme kursu hakkındaki görüşleri. 15. Spor Bilimleri Kongresi.15-18 Kasım 2017, Antalya, Türkiye, p:564-565.

Güray, E. (2002). İlköğretim Okullarındaki Öğrencilerin Beden Eğitimi Dersi Hakkındaki Düşünceleri ve Beklentileri (Gebze Örneği). Sakarya Üniversitesi Sosyal Bilimler Enstitüsü, Sakarya.

İlkim, M. (2006). Beden eğitimi öğretmenlerinin çalışma şartlarına göre beden eğitimi dersini nasıl işlediklerinin değerlendirilmesi İnönü Üniversitesi Sağlık Bilimleri Enstitüsü, Malatya.

İncirli, A., ilığan, A., Sirem, Ö., \& Bozkurt, S. (2017). Ortaöğretim destekleme ve yetiştirme kurslarına ilişkin öğrenci görüşleri. Mehmet Akif Ersoy Üniversitesi Eğitim Fakültesi Dergisi, (42), 50-68.

Kağıtçıbaşı, Ç. (2005). Yeni İnsan ve İnsanlar. (Onuncu Basım). İstanbul: Evrim Yayınevi.

Karadağ, E. (2010). Eğitim Bilimleri Doktora Tezlerinde Kullanılan Araştırma Modelleri: Nitelik Düzeyleri ve Analitik Hata Tipleri. Kuram ve Uygulamada Eğitim Yönetimi, 16(1), 49-71. 
Karakuş, E. (2005). Resmi Ortaöğretim Kurumlarında Beden Eğitimi Derslerinin Uygulamalarında Karşılaşılan Sorunlara illişkin Öğrencilerin ve Beden Eğitimi Öğretmenlerinin Görüşleri (Kırıkkale illi Örneği). Yayımlanmamış Yüksek Lisans Tezi, AÜ, Eğitim Bilimleri Enstitüsü, Ankara.

Kaya, S. (2011). Illköğretim okul yöneticilerinin, beden eğitimi öğretmenlerinin ve öğrencilerin okul spor programlarındaki fair play anlayışları: Bolu ili örneği, Abant İzzet Baysal Üniversitesi, Sosyal Bilimler Enstitüsü, Bolu

Koç, Y. (2013). Beden Eğitimi Dersi Sportmenlik Davranışı Ölçeği (BEDSDÖ): Geçerlik ve Güvenirlik Çalışması, Erzincan Üniversitesi Eğitim Fakültesi Dergisi, 15-1

Lincoln Y. S.,\& Guba, E. G. (1986). But is it rigorous? Trustworthiness and authenticity in naturalistic evaluation. New directions for evaluation, (30), 73-84.

Miles, M, B., \& Huberman, A. M. (1994). Qualitative data analysis: An expanded Sourcebook. (2nd ed). Thousand Oaks, CA: Sage.

Milli Eğitim Bakanlığı. (2013). Beden Eğitimi ve Spor Dersi Öğretim Programı (Ortaokul 5-8. Sınıflar). Ankara: Milli Eğitim Bakanlığı Talim ve Terbiye Kurulu Başkanlığı.

Milli Eğitim Bakanlı̆̆ı, (2014). Millî Eğitim Bakanlığı örgün ve yaygın eğitimi destekleme ve yetiştirme kursları yönergesi. 5 Temmuz 2019 tarihinde https://hbogm.meb.gov.tr/ adresinden erişilmiştir.

Milli Eğitim Bakanlığı. (2018). Örgün ve Yaygın Eğitimi Destekleme ve Yetiştirme Kursları Tanıtım Kitapçığı. Ankara:MEB Yayınları. 5 Temmuz 2019 tarihinde http://www.meb.gov.tr/sinavlar/dokumanlar/2017/dyk_kitapcik.pdf adresinden ulaşılmıştır.

Milli Eğitim Bakanlığı. (2019). Destekleme ve Yetiştirme Kursları e-Klavuzu. Ankara: MEB Yayınları. 5 Temmuz 2019 tarihinde https://www.meb.gov.tr/meb_iys_dosyalar/2018_09/05111501_DYK_e_kilavuz.pdf adresinden ulaşılmıştır.

Morgan,'dan, Aktaran: Tavşancıl, E. (2010). Tutumların Ölçülmesi ve SPSS ile Veri Analizi. Ankara: Nobel Yayınevi.

Nartgün, Ş. S., \& Dilekçi, Ü. (2016). Eğitimi destekleme ve yetiştirme kurslarına ilişkin öğrenci ve öğretmen görüşleri. Kuram ve Uygulamada Eğitim Yönetimi, 22(4), 537-564.

Ocak Y., Tortop Y. (2006). Sınıf Öğretmenlerinin Beden Eğitimi Derslerine iliş̧kin Genel Görüşleri ve Beden Eğitimi Derslerini Yürütürken Karşılaştıkları Sorunları, 9. Uluslararası Spor Bilimleri Kongresi, 3-5 Kasım, Muğla, 663669

Öncü, E. (2007). Ana-babaların çocuklarının beden eğitimi dersine katılımına yönelik tutumları ve beklentileri. Yayınlanmamış Doktora Tezi, Gazi Üniversitesi, Ankara

Ören, A. N. (2014). Öğrencilerin dershaneye yönelik düşüncelerinin analizi. Yayımlanmamış Yüksek Lisans Tezi. İstanbul: İstanbul Sabahattin Zaim Üniversitesi, Sosyal Bilimler Enstitüsü.

Özcan, G., Mirzeoğlu A.D., Çoknaz, D. (2016). Öğrenci gözüyle beden eğitimi ve spor dersi ve öğretmeni. Abant İzzet Baysal Üniversitesi Eğitim Fakültesi Dergisi, 16 (1), 270-291.

Özgüven, İ. E. (2005). "Bireyi Tanıma Teknikleri”, PDREM yayınları, 125, Ankara,

Özşaker M, Orhun A. (2005). Illköğretim okullarında beden eğitimi dersinin amaç ve içeriğine ilişkin sorunlar, 4. Ulusal Beden Eğitimi ve Spor Öğretmenliği Sempozyumu, 10-11 Haziran, Bursa, 103-114.

Pellicer-Chenoll, M., Garcia-Massó, X., Morales, J., Serra-Añó, P., Solana-Tramunt, M., González, L. M., \& Toca-Herrera, J. L. (2015). Physical activity, physical fitness and academic achievement in adolescents: a self-organizing maps approach. Health education research, 30(3), 436-448.

Sakallı, N. (2001). Sosyal Etkiler. Ankara: İmge Kitap Evi.

Salman M. N. Çalgın E. R. Salman S. (2005). Beden Eğitimi Öğretmenlerinin Mesleki Sorunlarının Cinsiyet Faktörü Açısından Değerlendirilmesi, Editör: GÜLTEKiN, O. 4. Ulusal Beden Eğitimi ve Spor Öğretmenliği Sempozyumu, Burfaş Ofset Tesisleri, Bursa.

Salman, U., Sarı, İ., \& Mirzeoğlu, A. D. (2018). Beden eğitimi öğretmenleri gözüyle sağlikla ilgili fiziksel uygunluk karnesi. İnönü Üniversitesi Beden Eğitimi ve Spor Bilimleri Dergisi, 5(3), 1-24. 
Sarıbaş, M. Pınar, A. (2018). Ortaöğretim son sınıf öğrencilerinin coğrafya dersinin sınav sistemindeki yerini bilmelerinin destekleme ve yetiştirme kurslarında coğrafya dersini seçmelerine etkisi üzerine bir araştırma. 1. International Geography Education Symposium, Nevşehir. Proceeding book, ISBN: 978-605-81180-2-7. (pp. 94106)

Shenton, A. K. (2004). Strategies for ensuring trustworthiness in qualitative research projects. Education for information, 22(2), 63-75.

Singh, A. S., Saliasi, E., Van Den Berg, V., Uijtdewilligen, L., De Groot, R. H., Jolles, J., ... \& Ericsson, I. (2019). Effects of physical activity interventions on cognitive and academic performance in children and adolescents: a novel combination of a systematic review and recommendations from an expert panel. Br J Sports Med, 53(10), 640647.

Şahin, D. (2011). Okul müdürü, öğretmen ve ebeveynlerin beden eğitimi dersine ilişkin görüşlerinin incelenmesi, Karadeniz Teknik Üniversitesi, Eğitim Bilimleri Enstitüsü, Beden Eğitimi Ve Spor Öğretmenliği Bilim Dalı

Tanrıverdi, í. (2016). Ortaokulda öğrenim gören öğrencilerin beden eğitimi dersine ilişkin tutumlarının karşılaştırılması (Van ili örneği), Ağrı İbrahim Çeçen Üniversitesi, Eğitim Bilimleri Enstitüsü, Ağrı

Taşkın, C. (2018). Ortaokul beden eğitimi ve spor dersi öğretim programı hakkında öğrenci ve öğretmen görüşleri, Trakya Üniversitesi, Eğitim Bilimleri Enstitüsü, Edirne.

Taşmektepligil, Y., Yılmaz, Ç., İmamoğlu, O., \& Kılcıgil, E. (2006). İlköğretim okullarında beden eğitimi ders hedeflerinin gerçekleşme düzeyi. Spormetre Beden Eğitimi ve Spor Bilimleri Dergisi, 4(4), 139-147.

Tavşancıl, E. (2002). Tutumların Ölçülmesi ve SPSS ile Veri Analizi. Ankara: Nobel Yayın Dağıtım, s:65, s80, s115).

Tokat, S. (2013). Beden eğitimi öğretmenleri ve okul yöneticilerinin Beden eğitimi ve spor dersinin etkinliği üzerine Görüşlerinin incelenmesi, Gazi Üniversitesi, Eğitim Bilimleri Enstitüsü, Beden Eğitimi ve Spor Öğretmenliği Anabilim Dalı, Ankara

Türkmen M., Varol S. (2015). Beden Eğitimi ve Spor Dersinin Ortaokul Öğrencileri Üzerinde Sportmenlik Davranışı Oluşturma Etkisinin Belirlenmesi: (Bartın Il Örneği), Uluslararası Güncel Eğitim Araştırmaları Dergisi (UGEAD), 1: $42-64$

Ünsal, S., \& Korkmaz, F. (2016). Destekleme ve yetiştirme kurslarının işlevlerine ilişkin öğretmen görüşlerinin incelenmesi. Kahramanmaraş Sütçü İmam Üniversitesi Sosyal Bilimler Dergisi, 13(2):87-118.

Yıldııım, A., \& Şimşek, H. (2008). Sosyal bilimlerde nitel arastirma yontemleri. Ankara: Seçkin.

Yılmaz, A. (2012). Ortaöğretim kurumlarındaki yönetici, beden eğitimi öğretmeni ve öğrencilerin beden eğitimi dersine ilişkin görüşlerinin tespit edilmesi: nitel bir çalışma. Karadeniz Teknik Üniversitesi Eğitim Bilimleri Enstitüsü, Trabzon. 